\title{
Osmanlı Döneminde Yerebatan Sarnıcı ve Mahallesi
}

\author{
Ayhan $\operatorname{Han}^{*}$
}

\begin{abstract}
Özet
Bizans yapılarının Osmanlı dönemi restorasyonları ve kent morfolojisindeki yeri hakkındaki araştırmalar belirli bina tipleriyle sınırlı kalmış ve sarnıçlar bu gruba dahil edilmemiştir. $\mathrm{Bu}$ çalışma, Yerebatan Sarnıcı'nın Osmanlı döneminde geçirdiği onarımları ve sarnıç üzerinde yer alan mahalleyi incelerken, sarnıçtaki onarımların kapsamını tespit etmeyi ve yapının kent ile kurduğu ilişkiye dair gözlemlerde bulunmayı amaçlıyor. Yerebatan Sarnıcı, üzerinde bulunan cadde, mahalle, ahırlar ve saraya hem ismini hem de zeminini vermişti. Bu çalışma, ilk olarak daha önce yayımlanmamış olan Yerebatan Sarnıcı'ın iki adet plan ve kesiti üzerinden sarnıç ve mahalleye dair bir analiz yapıyor. İkinci aşamada ise sokak dokusu ve cadde üzerindeki konut dizilerinin dönüşümü ve sosyal içeriğin belirlenmesi amaciyla mahallenin 1803 tarihli krokisi ve 1874 tarihli emlak defterini inceliyor. Zemin topografyasının belirleyici unsuru olan sarnıcın mahalle morfolojisini de şekillendirdiği sonucuna variliyor.
\end{abstract}

Anahtar kelimeler: Yerebatan, sarnıç, Osmanlı restorasyonları, Osmanlı mahallesi, cadde

\section{Yerebatan Cistern and Neighborhood during the Ottoman Period}

\section{Abstract}

Studies of the restorations of Byzantine structures during the Ottoman period and of their placement within the urban fabric have been limited to certain types of buildings; cisterns have not been among them. This study discusses the Ottoman restorations of the Basilica Cistern and the neighborhood built upon it. Its main purpose is to identify the Ottoman restorations carried out in the cistern and to explore the relationship of the structure to its urban landscape. The neighborhood, including its main street, stables, and palace, became known by the name of the cistern above which they were located, Yerebatan. The cistern's columns, arches, and vaults supported the ground and provided a flat surface upon which the neighborhood was built. First, the study aims to analyze the cistern and the neighborhood with the aid of two previously unpublished plans as well as a cross section of the cistern. Second, it seeks to identify the transformations in the street pattern, the layout of dwellings along the streets, and the social makeup of the area through the analysis of an 1803 sketch of the neighborhood and an 1874 property register. It concludes that the cistern, which became the key component of the ground topography in Yerebatan, shaped the neighborhood's morphology.

Keywords: Yerebatan, cistern, Ottoman restorations, Ottoman neighborhood, street 
82 Yerebatan Sarnıc1, İmparator loustinianos (527-565) döneminde bölgenin su ihtiyacının karşılanması amacıyla yapılmıştı. Mevcut imparatorluk stoasının avlusu ana kayaya kadar kazılarak sarnıcın haznesi meydana getirilmiş, sütun sıralarını bağlayan kemerler tonozlarla örtülmüştü. Osmanlı döneminde ise, temel özelliğini kaybetmeyen sarnıcın örtüsünün sağladığı düz satıh, üzerindeki mahalleye zemin oluşturarak yapıya yeni bir işlev kazandırdı. Osmanlıların Bizans dönemine ait eski suyollarını tamir etmesi ve yenilerini tesis etmesi, sarnıcın su dağıtım merkezi olma işlevini kısmen değiştirse de, üzerinde oluşan mahalle ve Cağaloğlu’nu Divanyolu ve Ayasofya Meydanı'na bağlayan Yerebatan Caddesi ile kent mekânında varlığını sürdürmeye devam etti. On sekizinci yüzyılda iktidar alanı genişleyen divan üyeleri ve paşaların konakları Topkapı Sarayı'na gidiş geliş güzergâhının merkezine yerleşti. Nitekim on sekizinci yüzyılın ilk yarısında Yerebatan Sarayı en önemli ikinci iktidar odağıydı.

Yerebatan Sarnıcı, merkezinde olduğu mahalleyi temsil eden fiziksel bir simge, mimari bir yapı ve locus haline geldi. İsmini saraya, sadrazamın ahırlarına, caddeye ve mahalleye verdi. Aldo Rossi, locus kavramını "belirli bir yer ile onun üzerinde bulunan yapılar arasındaki ilişki” olarak tanımlar. Locus, zamanla kentsel bir içeriğe dönüşür ve tekil bir yapı halini alır. Kavramın Türkçe karşılığı mahalle kelimesini türeten 'mahal'dir. Yerebatan da işlevi kısmen değişmesine karşın, İstanbul kent mekânında, Divanyolu eksenine açılan önemli güzergâhlardan birinin odağında yer alan, mahallenin tasarım ve doku özelliklerini belirleyen ve düzenleyen özel bir anıt yapıya dönüştü. Bizans katmanı üzerine inşa edilen Osmanlı katmanının yerleşim kümeleri dizilimi ve alt yapı düzenlemelerinden sokak dokusuna kadar mahalle mimarisinin karakterini oluşturdu.

İstanbul'daki Bizans yapılarının Osmanlı dönemindeki onarımları, dönüşümleri, kent mekânına katılımları gibi konularda oldukça sınırlı sayıda çalışma bulunuyor. Özellikle Bizans sarnıçlarının Osmanlı dönemindeki kullanımlarına dair bütüncül, kapsamlı araştırmalar yapılmamıştır. Bununla birlikte, açı sarnıçların bostana dönüştürülmeleri, kapalı sarnıçların ise bir yandan su depolamaya devam ederken bir yandan da üzerlerindeki yapı veya mahalleye zemin sağlamış olmaları mimarlık tarihi ve arkeoloji alanlarının araştırılmaya değer, müstesna başlıklarından birisidir. Bu makale, Osmanlı döneminde Yerebatan Sarnıcı'nın geçirdiği onarımlar ve üzerindeki mahalle aracılığıyla Bizans yapılarının Osmanlı mimarlık ve kent tarihi açısından önemine dikkat çekme amacını taşıyor.

\section{Bizans Döneminde 'Bazilika Sarnıcı'}

Mimari bir terim olan sarnıç, kent sakinlerinin su ihtiyacını karşılamak amacıyla genellikle yer altında inşa edilen, etrafı duvarla tahdit edilmiş, su geçirmez mahzen veya su haznesi anlamına gelir. Sarnıçta su depolamak için ya yağmur suyu biriktirilir ya da başka bir kaynaktaki suyun getirilmesi gerekir. İstanbul'daki sarnıçlar suyollarına bağımlıdır. Yaz aylarında artan su talebini karşılamak amacıyla Bizans imparatorları, özellikle loustinianos, birçok anıtsal sarnıç inşa etmiştir. On dokuzuncu yüzyıl tarihçisi Skarlatos Byzantios'un ifadesiyle "eğer suyolları 'akan nehirler' ise, kentin yedi vadisinin kayda değer büyüklükte alanlarını işgal eden devasa sarnıçlar birer deniz veya göl gibiydiler."2 Ioustinianos dönemi yapılarını anlatan Prokopios da, diğer mevsimlerde bol olan ve suyolları ile kente getirilen suyun arta kalanının, yaz mevsiminde ortaya çıkabilecek ihtiyacı karşılaması amacıyla imparatorluk stoası avlusundaki sarnıcın inşa edildiğini belirtir. ${ }^{3}$ Kuşatmalar sırasında, suyollarının bozulma tehlikesi bulunduğundan, kentin su ihtiyacının karşılanmasında sarnıçların stratejik bir önemi de vardı. ${ }^{4}$

Geç Roma döneminde suyun akışı tazyikle yönlendirilemediğinden ve tamamen yer çekimine bağlı olduğundan sarnıçlar, hizmet verdikleri yerleşimlerden daha yükseğe, tepe noktalara ve sırtlara inşa edilmişti. Örneğin daha yüksek irtifada bulunan Stoudios Sarnıcı Yedikule civarını beslerken; yine yüksekte bulunan Aspar Sarnıcı Kumkapı civarındaki mahallelere su

1 Aldo Rossi, The Architecture of the City, der. Peter Eisenman, çev. Diane Ghirardo ve Johan Oackman (Cambridge: MIT Press, 1984 ), 103. 2 Scarlatos D. Byzantios, Constantinople: A Topographical, Archaeological, and Historical Description, c. I., çev. Haris Theodorelis-Rigas (İstanbul: İstos, 2019), 186.

3 Prokopios, Yapılar, çev. Erendiz Özbayoğlu (İstanbul: Arkeoloji ve Sanat Yayınları, 1994), 42-43.

4 Charles Pertusier, Picturesque Promenades in and near Constantinople, and on the Waters of the Bosphorus (Londra: Sir Richard Phillips and Co. Bridge-Court, 1820), 30. 
tedarik ediyordu. Açık ve üzeri tonozla kapatılmış iki tür sarnıç bulunmaktaydı. Skarlatos'un Manuel Khrysoloras’tan aktardığına göre Latin işgalcileri döneminde açık sarnıçların birçoğu dolduruldu ve çukur bostanlara tahvil edildi. ${ }^{5}$

Konstantinopolis'in en büyük su mahzeni, Ayasoyfa'nın kuzeybatısında, Soğuk Çeşme Sokağı'nda bulunan Bazilika, yani Yerebatan Sarnıcı'ydı. Ioustinianos döneminde, 526-527 seneleri arasında inşa edilen sarnıç, denizden $30 \mathrm{~m}$ yüksekliktedir. Şehrin birinci ve ikinci tepeleri arasındaki bölgelerin su ihtiyacını karşılayan Hadrianus su yollarına bağlanmıştır. ${ }^{6}$ Prokopios, sarnıcın inşasını şöyle anlatır:

[A]vukat, davacı ve bu işlerle ilgili başka kimselerin davalarını hazırladıkları imparatorluk stoasında (porticus) çok uzun ve çok geniş bir avlu vardır ve bu avlu dört tarafında sütunlarla çevrilidir; yapının temelleri toprağa değil kaya (petra-saxum) üstüne atılmıştır. Avluyu, her biri bir kenarda olmak üzere dört adet sütun sıralı stoa (porticus) çevreler; İmparator lustinianus, güneye bakan stoanın çok derin olarak kazılmasını emretti ve buraya, yaz mevsimi dışındaki mevsimlerde çok bol olduğu için ziyan edilen suyun, yaz mevsimi için toplanacağı uygun bir su haznesi (eluthracisterna) yaptırd1.7

Şehre giren su kolu Ayasofya maksemine ulaşıp, oradan Yerebatan Sarnıcı'nı doldurmaktaydı. ${ }^{8}$ Sarnıç, kayalık bir zemine oturan, 138 × 64,6 m ölçülerinde ve dikdörtgen planlı, tuğladan inşa edilmiş bir yapıdır. Toplam 336 sütun, üzerindeki tuğla örgülü tonozu taşır. Doğubatı yönünde 28, güney-kuzey yönünde 12 sütun sırası bulunur. Sarnıcın, batısındaki alan çökmüştür. ${ }^{9}$ Kuzeybatısında kaba taştan örülmüss bir duvarı, molozdan oluşan ikinci bir duvar takip eder. ${ }^{10}$ Yapıda bezemeli sütun, Korint sütun başlıkları ve ters yüz edilmiş Medusalı başlıklar gibi devşirme malzemeler kullanılmıştır. ${ }^{11}$

Osmanlı döneminde bulunduğu yerden alçak alanlara, Hasbahçe içerisindeki kışla, Demir Kapı civarındaki konaklar, hamamlar ve hanelere; kısacası Sarayburnu ve Bahçe Kapısı civarına su dağıtım merkezi olarak hizmet sunmuştur. ${ }^{12}$

\section{Osmanlı Dönemi’nde Yerebatan Sarnıcı'nın Özgeçmişi}

Geç Bizans döneminde sarnıç yapımı durdu. Depremlerden zarar gören sarnıçlar ya restore edilmedi, ya da büyük oranda terk edildi. İstanbul'un fethinden hemen sonraki tarihi kaynaklarda sarnıçlardan bahsedilmez. Örneğin, 1455 tarihli ilk İstanbul tahririnde, daha sonraki dönemde İmrahor Camii'ne dönüştürülecek olan Stoudios Manastırı yerleşkesinde, iki katlı bir tımarhane, büyük bir şaraphane, iki adet kilise gibi yapılardan bahsedilse de sarnıç kayıt dışında bırakılmıştır. ${ }^{13} 1472$ tarihli Fatih Sultan Mehmed Vakfiyesi'nde ise Ayasofya civarının anlatıldığı bölümde, "çok sayıda eski hucra, bitişik, Bodrumlar denilen, Ayasofya dışında" ${ }^{\prime 4}$ ibaresi olsa da bunun hangi sarnıca işaret ettiğini tespit etmek zordur. Ancak bahsi geçenin Yerebatan Sarnıcı olmadığını söylemek mümkündür, çünkü sonraki yüz yıllarda yapılan yazışmalara göre sarnıç hiçbir zaman vakıf malı olmadı. ${ }^{15}$

1544-1555 tarihleri arasında İstanbul'da yaşayan doğa bilimci ve topografya uzmanı Petrus Gyllius'un Yerebatan Sarnıcı anlatımındaki detaylar, sarnıcın Osmanlı dönemiyle ilgili toplumsal hafızada yer edinmiş unsurların hemen hepsini içermesi bakımından önemlidir. $\mathrm{Bu}$ anlatıya göre, sarnıcın üzerindeki mahalle sakinleri sarnıçtan 'haberdardır': Kovalarla

5 Byzantios, Constantinople, 186-187.

6 Jim Crow, Jonathan Bardill ve Richard Bayliss, The Water Supply of Byzantine Constantinople (Londra: Journal of Roman Studies Monography, 2008), 114.

7 Prokopios, Yapılar, çev. Erendiz Özbayoğlu (İstanbul: Arkeoloji ve Sanat Yayınları, 1994), 42-43; Buildings, c. 7, çev. B. Dewing ve Glanville Downey (Londra: Loeb Classical Library, 1971), 91, 93.

8 Kazım Çeçen ve Celal Kolay, Topkapı Sarayı'na Su Sağlayan Isale Hatları (İstanbul: İSKi, 1997), 33; Byzantios, Constantinople, 619.

9 Wolfgang Müller-Wiener, İstanbul'un Tarihsel Topografyası, çev. Ülker Sayın (İstanbul: Yapı Kredi Yayınları, 2016), 284.

1o Senhaz Önlü, "Yerebatan Sarnıcı'nın Taşıyıcı Elemanlarının Analizi” (yüksek lisans tezi, İstanbul Teknik Üniversitesi, 2010), 30-31.

11 Crow, Water Supply, 114; Kerim Altuğ, "İstanbul'da Bizans Dönemi Sarnıçlarının Mimari Özellikleri ve Kentin Tarihsel Topografyasındaki

Dağılımı" (doktora tezi, İstanbul Teknik Üniversitesi, 2013), 6o-62.

12 BOA, I.MMS. 7/124 vrk. no. 4 (1846).

13 Halil İnalcık, The Survey of Istanbul 1455 (İstanbul: Türkiye İș Bankası Kültür Yayınları, 2012), 351-352.

14 Ahmet Beyatl, haz., Fâtih Sultan Mehmed'in 877/1472 Tarihli Vakfiyyesi (Ankara: Türk Tarih Kurumu, 2013), 213.

15 BOA, BEO. 4676/350640 vrk. no. 1 (27 Cemaziyelevvel 1339 [7 Mart 1921]). 
84 su çekerler; hatta sarnıç içerisinde kürek çekip kandillerle ışıklandırır ve balık avlarlar. Kuyulardan sarnıç içerisine hava ve ışık sızmakta, balıklar ışığın altında yüzmektedirler. Gyllius, sarnıcın ölçülerini 336 ayak uzunluk ve 182 ayak genişlik, çevresini ise 224 Roma adımı olarak tespit eder. Örtüsü, kemerleri ve etraf duvarları tuğladan yapılmıştır. 336 mermer sütun sayar ve tepesinde birçok kuyu olduğunu belirtir. ${ }^{16}$ Petrus Gyllius burayı yeniden 'keşfeder' veya daha doğru bir ifade ile Prokopios'un anlatısında yer alan stoa avlusunda yapılmış "Bazilika Sarnıcı" olarak tanımlar.

$\mathrm{Bu}$ yapı, Gyllius'un yerini tanımlamasının ardından Fransız sefiri Antoine-François Andréossy'nin 1818 senesinde sarnıcı 'yeniden keşfine' kadar Batılı seyyahlar nezdinde 'kaybolmuştur.' Galatalı bir Frenkin iki senelik uğraşıyla yeri tam olarak saptanmış ve sarnıcın girişindeki ev sahibinin de onayı ile seyyahların uğrak yerlerinden birisi olmaya başlamıştır. ${ }^{17}$ Yine Batılı seyyahların Yerebatan Sarnıcı anlatılarında, mimari tanımlamalara gizem, bilinmeyene yapılan korkuyla karışık ve heyecan verici bir yolculuğun kurgusu eşlik eder. ${ }^{18}$

Petrus Gyllius'un İstanbul ziyaretinden yaklaşık yirmi beş sene sonra, 1581 senesinde İstanbul kadısı, mimari ve Ayasofya Camii Vakfı mütevellisine gönderilen bir hüküm de Ayasofya yakınında Üskübî Mahallesi’nde "Herseklioğlu bodrumu" diye anılan bir yerden bahseder. Bodrumdaki suyun has bahçeye aktığı ancak mahallede biriken çöpler nedeniyle suyun kirlendiğinden şikayetçidir. "Yaya kaldırımının" altından açılan yeni bir lağım yolu ile kirli suların Ayasofya karizine katılması gerekmektedir. ${ }^{19}$ Üskübî Mahallesi ismiyle anılan yer on sekizinci yüzyıl başında Yerebatan Mahallesi'ne; "Herseklioğlu bodrumu" ismi ise Yerebatan Sarnıcı'na dönüşecektir. Mahalle, ismini 1491 senesinde yapılan Üskübî İbrahim Ağa Mescidi'nden alır. Evliya Çelebi seyahatnamesinde ise "Ayasofya'da Hersek bodrumu üzre Ağa mescidi” ${ }^{20}$ olarak kayıt edilmiş bir mescit bulunur. Ancak seyahatnamede Yerebatan ismine rastlanmaz. Bu nedenle Yerebatan isminin yaklaşık olarak 170o'lerin başından itibaren kullanıldığını söylemek yanlış olmayacaktır.

On sekizinci yüzyıl Osmanlı kaynaklarında, sarnıç 'Yerebatan' ismiyle anılmıştır. Günümüzde Yerebatan Sarayı olarak tarif edilen yapı, esasında bugüne ulaşmayan Bıyıklı Mustafa Paşa Sarayı'dır; sarnıç değildir. Bununla birlikte sarayın mahalle mekânında tortu bırakıp, isminin dilde devamlılığının olması ve canlılığını yitirmemesi, mahalleyi şekillendiren mimari katmanlardan birisinin belirlenmesi açısından önemlidir. Yerebatan Sarayı, bugünkü Cağaloğlu Hamamı'nın bulunduğu mevkide, Çatal Çeşme Sokağı'ndaydı. Mehmed Ziya Bey, Esad Efendi Kütüphanesi'nin kuzeyinde yer alan IIl. Ahmed'in kızı ve Damat İbrahim Paşa'nın eşi Fatma Sultan'a intikal eden bir saraydan bahseder. ${ }^{21}$ Bu yapı 1694 tarihinde vefat eden Bıyıklı Mustafa Paşa'ya aitti ve o dönemde Paşa Kapısı ismiyle anılan Bâbıâli'ydi. 1709 tarihinde saray hareminin dışına çevre duvarları inşa edildi. Döneme ait bir belgede "Defa Todori Arnavudun Ağalar Dairesi karşısında su hazinesine varınca duvarı meâ-temel" ifadesindeki su haznesi Yerebatan Sarnıcı'dır. ${ }^{22}$ Ahmet Refik, Ill. Ahmed'in kızı Fatma Sultan evlendiğinde buraya taşındığı notunu düşer: "Fatma Sultan'a münâsib bir saray lazımdı. En muvâfıkı, Paşa Kapısı civârında defterdarlara mahsus saraydı. Bu saray sabık veziriazam Bıyıklı Mustafa Paşa’nındı. Ahmed-i Sâlis, sarayın Fatma Sultan’a ihsanını emr eylediği gün Defterdar Efendi ile beraber hâcegân-1 divân 'Suyabatan' Sarayı'na geçmişlerdi. ${ }^{23} 1740$ 'da saray ve müştemilatı yandı. Sarnıç girişi ve Çatal Çeşme civarında bulunan arsalarına sadrazam atlarının barınması için ahırlar inşa edildi. Ayrıca yukarıdaki örneğe rağmen 'Suyabatan' kelimesi, sarnıcı ve bölgeyi tarif ederken kullanılan yerleşik bir tabir değildir. Ancak, 1789 yllında, kendisine bir hane tedarik edilmesi başvurusunda bulunan ve 'Suyabatan'da kiralık bir evde yaşayan hekimbaşı gibi örneklere rastlamak da mümkündür. ${ }^{24}$

16 Petrus Gyllius, The Antiquities of Constantinople, çev. John Ball (Londra: John Ball ve C.C.C: Oxon, 1729), 146-147.

17 Robert Walsh ve Thomas Allom, İstanbul Manzaraları: Rumelide ve Batı Anadolu'da Gezintilerle, çev. Şeniz Türkömer (İstanbul: Türkiye iş Bankası Kültür Yayınları, 2013), 51 .

18 Julia Pardoe, The Beauties of the Bosphorus (Londra: George Virtue, 1838), 101-105.

19 BOA, A.DVNSMHM.d. 42, hüküm no: 671 (3 Safer 989 [9 Mart 1581]).

20 Evliya Çelebi, Evliyâ Çelebi Seyahatnâmesi, Topkapı Sarayı Kütüphanesi Bağdat 304 Numaralı Yazmanın Transkripsiyonu-Dizini, c. 1, haz., Robert Dankoff et al. (istanbul: Yapı Kredi Yayınları, 2006), 148.

21 Mehmed Ziya Bey, İstanbul ve Boğaziçi: Bizans ve Osmanlı Medeniyetlerinin Âsâr-ı Bâklyesi (İstanbul: İstanbul Büyükşehir Belediyesi Kültür A.Ş. Yayınları, 2016), 601-602.

22 Sarayın tamir masraf defteri ve örülen çevre duvarları için bkz: BOA, D.BŞM 1610/40 vrk. no. 2 (18 Rebiülevvel 1121 [28 Mayıs 1709]).

23 Ahmet Refik Altınay, Fatma Sultan (İstanbul: Diken-İnci Matbaası, tarihsiz), 11-12.

24 BOA, AE.SABH I. 24657 vrk. no. 1 (10 Receb 1203 [6 Nisan 1789]). 
İstanbul sakinlerinin yaz aylarında tecrübe ettiği su kıtlığının önlenmesi hem suyollarının hem de sarnıçların restore edilmesine bağlıydı. On dokuzuncu yüzyılın ortasında Belgrad ve Bahçeköy'deki yedi adet bentten, İstanbul ve Galata bölgesine, yol üzerinde katılan sularla birlikte toplam 349 mahalden su gelmekteydi. Zaman içerisinde suyolları ve sarnıçların eskimesi, suların büyük oranda zayi olmasıyla sonuçlandı. Sarnıçlar suyla birlikte gelen kum ve toprak ile dolmaktayd ${ }^{25}$ ve mevcut sarnıçlar yaz aylarında ancak bir ay kadar hizmet sunabilir hale gelmişti. ${ }^{26}$ Çeşitli defalar suyolları onarılsa da, Yerebatan Sarnıcı'nın kapsamlı bir biçimde tamirine dair girişimler ancak 1846 tarihinde gündeme gelmiştir. ${ }^{27}$

1846 tarihinden önce sarnıca kısmi müdahaleler yapıldı. Özellikle Ayasofya Meydanı tarafındaki bölge bu onarımların odağındaydı. Ayasofya Camii'ne giden yolun altındaki kemerlerin çöküp yolun ikiye ayrılması nedeniyle 1722 senesinde sarnıçta yapılan çalışmalar, tespit edilen ilk restorasyon teşebbüsüdür. Kahve mukaatası emini İvaz Mehmed Ağa marifetiyle bu müdahale gerçekleşti. Mimar Ali Ağa ve hassa mimarbaşısı Kayserili Mehmed Ağa’nın keşif defterine göre restorasyon esnasında sarnıçtaki "sekiz adet kubbelerin tahtına müceddeden tuğla ile cila sıvalı sekiz adet payeler" yerleştirildi ve tonozun örülmesiyle açılılı kapatıldı. ${ }^{28}$

1790 senesinde olasılıkla yine aynı bölgeye bir başka müdahale yapıldı. 1803 tarihli mahalle planı Yerebatan Caddesi girişini “Mehterhâne tarafında dörtyol ağzı" olarak işaretler (şek. 3). ${ }^{29}$ Burada sadrazam mehterleri (tabl-ı alem) neferâtının sakin oldukları bir bina bulunmaktaydı. Binanın altındaki kemerler, sütunlar ve duvarların çökmesi nedeniyle mimarbaşı Ebubekir bir keşif defteri hazırladı, ancak sarnıçtan bahsetmedi. Yine de defterdeki bazı ifadeler çöken yerin sarnıç olduğunu doğrular niteliktedir. Defterde, bahsi geçen mahallin cadde tarafında, bina altında bulunan duvarın bir kısmının yıkılmış ve diğer bir kısmının da yıkılmak üzere olduğu tespit edilmiştir. Restorasyon kapsamında aslına uygun olarak hatıl ve duvar, kireçle karıştırılmış tuğla ve taşlarla yeniden örülür ("mevcud esas üzerine hatıl ve püştivânlı turâbı kireç memzûc taş mahlût duvar tecdidi”). Yol tarafında ve bina altında olan duvar yaklaşık 12 x 0,75 x 3,75 m (16 x 1,3 x 5 zirâ) ölçülerindedir. Duvara, horasan kireci derzi gerekmektedir. Yeniden örülecek olan duvarın bina altında olması nedeniyle, yapıya sağlamlık kazandırmak için on adet "çifte mâneden sütun mâa başluk" kullanılacaktır. Bahsi geçen on başlık ile birlikte sütunlar olasilıkla sarnıcın yıkılan kısmından tedarik edildi. ${ }^{30}$

1765 tarihli, Yerebatan ahırlarının tamiratı için hazırlanan bir keşif defterinde sarnıca doğrudan bir atıf yoktur ancak sarnıç girişi tarafında yıkılmış olan tonozların kapatıldığını çağrıştıran bir takım veriler bulunmaktadır. Deftere göre "Yerebatan tarafında" yıkılmış olan taş duvarlar yenilenmiş ve duvarı yükseltmek için üzerine başka bir duvar daha örülmüştür. Hemen akabindeki bilgi notu, yenilenen su kuyusunun tulumbasından bahseder. Bahsi geçen tulumba suyu olasilıkla sarnıçtan çekmekteydi. ${ }^{31}$

1805 senesinde ise mimarbaşı İbrahim Kâmi, Yerebatan ahırlarının bahçe tarafında yıkılmış olan sed duvarı, arabaların teknik bakımında kullanılan aletlerin korunması için sundurma, yemlik ve kalkan duvarını inşa eder. Bu tarihte yapılan çalışmalar esasında ahırlarla ilgilidir. Aynı şekilde "gerek Yerebatan suyu ve gerek yan tarafında bağçe üzerinde münhedim olan duvar" ifadesi ve mavna kiralarından söz etmesi çalışmanın sarnıçta yoğunlaştığını kesinleştirir. İbrahim Kâmi, duvarların "mahlu moloz" ile yapılması nedeniyle yıkıldığını gözlemler. Yerine bu defa horasan derzli bir set duvarı yapılmasını tavsiye eder (6,3 x 1,12 x 7,5 m). Set duvarı üzerine bir de kalkan duvarı örülecektir. ${ }^{32} \mathrm{Bu}$ tarihte yapılan çalışmalarda mavnaların kullanılması dikkat çekicidir. Çünkü sarnıca kapsamlı bir müdahale, sarnıçtaki suyun boşaltılıp çamurun temizlemesine bağlıydı. Bu girişim için 1846 senesini beklemek gerekecekti.

25 BOA, I.MMS. $7 / 124$ vrk. no. 4 (1846).

26 BOA, I.MSM. 7/127 vrk. no. 7 (3 Cemaziyelahire 1262 [30 Nisan 1846])

27 "...emsâli olmadığı cihetle tahmin kâbilinden." BOA, İ.MSM. 7/127 vrk. no. 7 (3 Cemaziyelahire 1262 [30 Nisan 1846]).

28 BOA, MAD. 8947 s. 153 (11 Safer 1135 [ 21 Kasım 1722]). Ayrıca bkz. Muzaffer Erdoğan, Lale Devri Başmimarı Kayseri'li Mehmed Ağa,

(İstanbul: İstanbul Fetih Cemiyeti Yayınları, 1962), 27.

29 BOA, C.ML. 21757 vrk. no. 1 (1803)

30 BOA, C.AS. 24308 vrk. no. 1 (3 Recep 1204 [19 Mart 1790])

31 BOA, C.DH. 1177 vrk. no. 2 (27 Zilhicce 1178 [17 Haziran 1765]).

32 BOA, C.ML. 28289 vrk. no. 3 (9 Rebiülahir 1220 [7 Temmuz 1805]). 
86 Sarnıcın herhangi bir vakfa temlik edilmediğine daha önce değinmiştim. Bunun sonucunda, pek çok defa sarnıcın onarımına dair kararlar alınsa da, yüksek meblağlara mal olacağı anlaşıldığından, masraflar hazinece karşılanmadı: Onarım faaliyetleri, içerisindeki çamurun temizlenmesi için atılan adımlarla sınırlı kaldı. 1846 tarihinde Belgrad bentleri, Yerebatan ve Sultan Ahmed Camii civarında Rüstem Paşa’nın kılıçhane altında inşa ettirdiği sarnıçların tamir edilmesi gündeme geldiğinde, vakıf tarafından masrafların karşılanabilir olmasından dolayı sadece on sekiz gözlü Rüstem Paşa Sarnıcı'nın tamiratıyla yetinildi.33

Bu dönemde sarnıç "pek eski şey" olarak tarif edilir. ${ }^{34}$ Çamur nedeniyle zemindeki aksaklıklar belirlenememektedir. Sarnıcın tek bir girişinin olması, içerisinde sallarla manevra kabiliyetinin kısıtllı̆ı̆ı ve çamurun fazlalığı çalışmaya engel olan nedenlerdendi. Sorunların çözümüne dair birkaç defa rapor düzenlenmiş ve tamir masrafları çıkarılmıştır ancak yukarıda sayılan üç nedenden dolayı hazırlanan keşif defterleri gerçekçi bulunmaz. Nihayetinde Tersane-i Amire'den bir adet sandal getirilir ve birkaç suyolcu ve hamamcı ustası ile sarnıca girilerek onarılması gereken yerler belirlenir ve bir de plan çizilir. Suyolcu ve hamamcı ustalarının bildirdiğine göre sarnıcın içerisinde bazı yerlerde üç bazı yerlerde ise bir zirâa ${ }^{35}$ kalınlığında çamur bulunmaktadır. Duvarların sıvaları yer yer dökülmüş, Esad Efendi Konağı'nın taşra avlusu altında kalan kemerler çok zaman önce yıkılmış ve içerisine toprak ve moloz dolarak arsa halini almıştır. Söz konusu yıkılan yeri onarmak amaciyla daha önce set işlevi gören bir duvar yapılmış olsa da bu duvarın iki tarafı su tutmamaktadır. Bu duvar olasılıkla İbrahim Kâmi’nin 1805 senesinde ördüğ̈ duvardır. Buraya tuğla ile karışık horasan ve lökünden sıvalı bir perde duvarı inşası ve diğer kısım duvarın önüne ise kilitli moloz dökülmesiyle sorunun çözüme kavuşacağı yönünde ustalar görüş bildirirler. ${ }^{36}$

Rapor yine gerçekçi bulunmaz ve "emsali olmadığı cihetle tahmin kâbilinden"37 olacağg 1 düşünülerek yeni bir rapor istenir. Bu kez sarnıcın içerisinde 200 x 80 x 4 zirâ boyutlarında bir çamur tabakası tespit edilir. ${ }^{38}$ Erişimin kolay olduğu yerlerdeki çamurun sallarla temizlenmesi düşünülür. Manevra kabiliyetinin kısıtlı olduğu yerlerdeki çamurun ise kış aylarında bent fazlası suyun sarnıca verilerek Zeynep Sultan Türbesi karşısındaki çeşmeye ve Şevkiye Köşkü civarındaki haznelere açılacak iki adet tünel (ana lağım yolu) yoluyla ${ }^{30}$ boşaltılması planlanır. ${ }^{40}$

\section{Sarnıcın Illk Plan ve Kesiti}

Raporda bahsi geçen ana lağım yollarının açılıp açılmadığı belirsizdir. Ancak, 1858'de sarnıcın "çirkap tarikinin" tamiriyle ilgili ödenek ayrıldığına dair bir ayrıntı bulunmaktadır. ${ }^{41}$ 1846 senesinde yapılan yazışmalarda bir mimar ismi zikredilmez. Suyolcu ve hamamcı ustalarının sandalla sarnıcı teftiş ettikleri ve sonucunda bir adet mazbata ve resm ${ }^{42}$ sundukları bilinmektedir.

Bu tarihlerde içerisinin karanlık olması ve dipteki çamur tabakasının büyüklüğü nedeniyle sarnıcın doğru bir planının çıkarılması zordu. İstanbul'un anıt yapılarını resmeden yabancı mimar ve ressamların da bu elverişsiz koşullarda sağlıklı bir üretim yapmaları mümkün değildi. Örneğin, Thomas Allom’un gravürü 1şığın yeterli olduğu giriş kısmı ile sınırlı kalmıştır. ${ }^{43}$ Suyolcu ve hamamcı ustalarının ise sandallarla gruplar halinde, resmi ve teknik kısıtlamalar olmadan sarnıç içerisinde keşif yapmalarının önünde bir engel yoktu. Dolayısıyla, sütun aralarını düzenli bir oranla gösteren, farazi çizilmiş geç tarihli diğer planların aksine, sarnıcın detaylarını olduğu şekilde aktaran ve şimdiye dek keşfedilmiş en erken tarihli belge su yolcu ve hamamcı ustalarının hazırladıkları plandır (şek. 1).

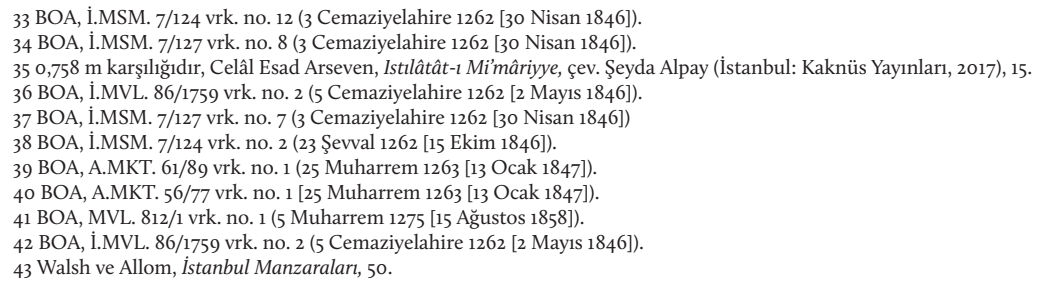




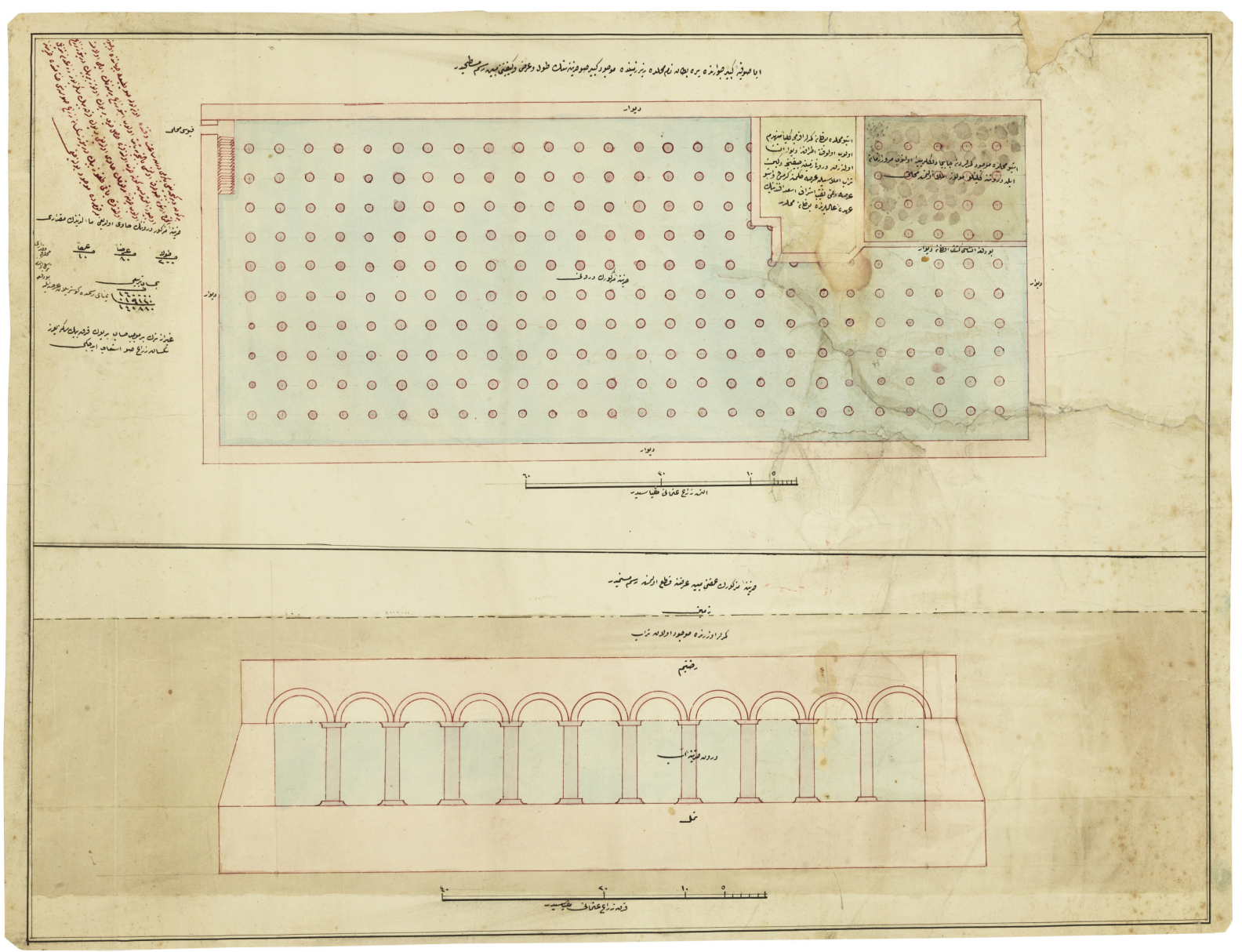

Şekil I: "Ayasofya yakınındaki Yerebatan isimli mahalde yer altında mevcut büyük su hazinesinin uzunluk ve genişliğini gösterir, düz bir yüzey üzerine çizilmiş resimdir ve bahsi geçen sarnıcın yüksekliğini içeren, enine kesiti gösteren düz bir zemin üzerine çizilmiş resimdir." BOA, PLK.p. 646 (1846).
Plan, sarnıcın vaziyet planı ve kesitini sunan iki çizim ve eşlik eden notlardan oluşmaktadır. Vaziyet planı şu şekilde açılanır: "Ayasofya-ı Kebir civârında Yerebatan nam mahalde zîr-i zeminde mevcud kebir su haznesinin tul ve arz ve keyfiyetini mübeyyin resm-i mustattahdır. Altmış zirâ Osmani mikyâsıdır." Kesiti anlatmak için ise "hazine-i mezkûrun umkunu mübeyyin arzına kat olunmuş resmi mustattahdır" ifadesi kullanılır. "Kırk zirâ-1 Osmani mikyâsıdır." Planda tarih belirtilmemiştir. Ancak 1846'daki yazışmalar ve plan notları arasındaki bazı ifadelerin benzerliği; ayrıca söz konusu yazışmalarda sarnıcın mevcut durumu ile ilgili bazı saptamaların plan notları ile uyumluluğu neticesinde planın tarihini 1846 olarak tanımlamak yerinde olacaktır.

1846 tarihli yazışmalarda, Esad Efendi Konağı'nın taşra avlusu altındaki kemerlerin yıkılıp arsa halini aldığına dair ve sarnıcın su tutmasını sağlamak için bu mahalde inşa edilmesi düşünülen perde (estar) duvarları hakkında çeşitli gözlemler bulunmaktaydı. Skarlatos Byzantios da, planın yaklaşık tarihini doğrularcasına, sarnıcın bir kısım kemerlerinin yıkıldığını ve açılan delikten içeri 1şık girdiğini gözlemler. ${ }^{44}$ Erdem Yücel, Abdülmecid döneminde (1823-1861), uzunluğuna 18, genişliğine ise 5 sütun sırasını sarnıcın haricinde bırakan, sarnıcın güneybatı cephesine bir duvar yapıldığı notunu düşer. ${ }^{45} \mathrm{Bu}$ kısım ve duvar planda gösterilmiştir. Sütun kalınlıkları ve sıraları diğer planlarda olduğunun aksine simetrik bir düzende gösterilmez ve devşirme malzemelerin varlı̆̆ına işaret eder. 
88 Sarnıçla ilgili restorasyon teşebbüslerinin olduğu günlerde, Kasım 1846'da, Esad Efendi'nin Yerebatan'da bulunan hanesini, topladığı nefis kitapları kamu yararına sunmak amacıyla kütüphaneye tahvil etmek istediği bilinmektedir. ${ }^{46}$ Bunun, avlunun altında kalan arsanın istimlak edilmesini önleme yönünde bir teşebbüs olduğunu iddia etmek haksızlık olmayacaktır. Plan notlarında da bahsi geçen Esad Efendi Konağı ve avlusundan kütüphane diye bahsedilmez; zaten kütüphane binası da 1848'de bitirilmiştir. Avlunun altındaki kısım, kemerlerin hepten yok olduğu, yer yer kemerlerle ve sütunların bulunduğu mahaller olmak üzere iki kısımdan oluşmaktadır:

\begin{abstract}
İşbu mahalde bulunan kemerler akdemce külliyen münhedim olub ol-vakt etrafına dıvar inşa olunarak derunu zeminden çıkınca değin turab imlâsıly arsa hükmüne girmiş ve işbu arsa dahi nakibü'l-eşraf Esad Efendi'nin uhde-i âlilerinde bulunan mahaldir;
\end{abstract}

İşbu mahalde mevcud kemerlerden câ-be-câ direkler peyda olunup murûr-1 zaman ile derûnuna külliyetli moloz imlâ olunmuş mahal

Sarnıcın köşesinde yer alan bu kısmın alt tarafına ise "bu dahi inşâsı keşf olunan duvar" notu düşülmüştür. Kapı tarafı ve merdiven mahallinin gösterildiği tarafta ise kısaca yirmi dört saatlik zaman diliminde harcanan su miktarı ve sarnıcın su tutma kapasitesi hesaplanmıştır. Sarnıcın kesit detayları ise aşağıdan yukarıya doğru temel, sarnıcın içerisindeki sütunlar, kemerler ve tonozlar ile üzerindeki mevcut toprak katmanı ve son olarak ise zemini gösterir.

\title{
Sarnıcın Mahalleyle ve Mahallenin Sarnıçla İmtihânı
}

Gülru Necipoğlu, 1459-1478 yılları arasında inşa edilen Topkapı Sarayı'nın Osmanlı hanedanı ve İstanbul halkı arasındaki mekânsal ilişkiyi yeniden kurgulayan bir yerleşke olduğunu söyler. Özellikle, çevre duvarlarının hanedan üyeleri ve şehrin geri kalanı arasında bir perde işlevi gördüğünü ve sultanın toplumdan uzağa, saraya çekildiğini vurgular. Saray bürokratlarının birbirleriyle ve sultanla olan ilişkilerini düzenleyen yeni teşrifat kuralları bu sürece eşlik etmiştir. Necipoğlu, on sekizinci yüzyılda bahsi geçen teşrifat kurallarının gevşediğini ve hanedanın izolasyonunun Boğaziç̧’nde yapılan sahil saraylarıyla değiştiğini belirtir. ${ }^{47}$ Bununla birlikte bu yüzyılda hanedan, divan üyeleri ve paşaların toplumla kurdukları yeni tür ilişkinin diğer bir yönünde ise Divanyolu ekseninin öneminin artmasını göz önünde bulundurmak gerekir.

Topkapı Sarayı'nın etrafındaki konut dokusuna olan kapsamlı etkisini tayin etmek zordur. Ancak sarayda çeşitli kademelerde çalışan ve sarayda kalmayan görevliler, saraya kolay ulaşılabilir mahallerde yaşamak mecburiyetindeydi. Yerebatan Mahallesi onlardan biridir. Topkapı Sarayı'nın bölge üzerindeki etkilerinden biri, sarayın yakınında bulunan mahallelerde, özellikle saraya bakan kısımlarındaki konutlara kat sınırlaması getirilmesiydi. Bu durumdan, Yerebatan Mahallesi de etkilendi. Örneğin, Mutfak Emini Osman Ağa Yerebatan'da bir hane ve Üsküdar Sırayalılar'da bir sahilhanenin sahibiydi. ${ }^{4}$ Vefatından sonra eşi ve kızı Yerebatan'daki evin üst katını yeniden yaptırmışlar, ancak mimar ağa Topkapı Sarayının bazı yerlerine nezareti olması nedeniyle yıktırmıştı. Padişah ise, sarayı görmediği sürece üst katların yapilabileceği konusunda izin verdi. ${ }^{49}$

Yerebatan Mahallesi, on sekizinci yüzyılın sonunda sarnıcın ismini almışır. Daha öncesinde, üzerindeki mescide referansla Üskübî Mahallesi olarak biliniyordu. Burası, Topkapı Sarayı ve sadrazam konakları gibi büyük ölçekli yerleşkeler ve ayrıca Divanyolu gibi kentin ana arterinin ortasında kalmış küçük ölçekli konutlardan oluşan bir mahalle hüviyetindeydi. Mahalle kuzeydoğu sınırında, Yerebatan Caddesi ile Divanyolu'nun kesiştiği noktada Milion Taşı, ayrıca su terazisi; doğusunda Divanyolu; güneydoğusunda Zeynep Sultan Camii; güneyinde Şengül Hamamı Yokuşu; kuzeyinde Bıyıklı Mustafa Paşa Sarayı yerleşkesi ve

46 BOA, C.MF. 21757 vrk. no.1 (8 Zilhicce 1262 [27 Kasim 1846]).

47 Gülru Necipoğlu, Architecture, Ceremonial, and Power: The Topkapı Palace in the Fifteenth and Sixteenth Centuries (Cambridge: MIT

Press, 1991), 22, 258.

48 BOA, AE.SABH. I. 9444 vrk. no. 1 (28 Safer 1199 [11 Ocak 1785])

49 BOA, HAT. 214/11689 vrk. no. 1 (29 Zilhicce 1205 [29 Ağustos 1791]). 
kuzeybatısında Çatal Çeşme Sokağı ile çevrelenmişti. İçerisinde Topkapı Sarayı'na nâzır iki katlı yapı bulunmamaktaydı. Evlerin çoğunluğu ahşaptan ve bir kısmı bahçeliydi. Divanyolu üzerinde su terazisi sırasındaki Hacı Beşir Ağa Çeşmesi, Cağaloğlu Hamamının önündeki çeşme ve Ayasofya yakınındaki Soğuk Çeşme mahalleye en yakın çeşmelerdi.

Sarnıcın sütunlar ve kemerlerle taşınan tonozlu örtüsü, radye temel (rıhtım) misali mahalleye düz bir zemin sağladı. Zemin topografyasının, mahalledeki yapı adaları ve sokak dokusunu, dolayısıyla mahallenin genel morfolojisini belirlediği yönünde birçok ipucu bulunmaktadır. Sarnıç, Karanlık Sebzevatçı Sokağı'ndan başlayıp Salkım Söğüt Sokağı'na uzanıyor ve sarnıcın üzerindeki Yerebatan Caddesi mahalleyi ikiye ayırıyordu. Mahallenin yayıldığı alan, sarnıcın sınırlarından daha büyüktü. Özellikle Şengül Hamamı Yokuşu civarında sert bir eğim başlıyordu. Etrafı saray yerleşkeleri, kütüphaneler, cami ve medreselerle donatılmasına rağmen, tonoz (rıhtım) üzerinde bulunan 1 metre kalınlığındaki toprak, kâgir bir bina için temel atmanın önünde engeldi. Bu nedenle Fatih Sultan Mehmed'in şatırcıbaşısı Mehmed Ağa’nın 1465 yilında inşa ettiği ve Üskübî İbrahim Ağa'nın 1491 yllında yenilediği, küçük bir yapı olan Üskübî Mescidi ${ }^{50}$ dışında mahallede cami, hamam, okul, kütüphane, saray gibi yapılar yoktu. Bir sebili de bulunan mescidin, suyu nereden tedarik ettiği konusunda bilgi bulunmamaktadır. Bıyıklı Mustafa Paşa Sarayı'nın avlu kısmı mahalle sınırları içinde olsa da binanın ana kütlesi, sarnıcın üzerinde değildi.

Sarnıcın engebesiz ve düz bir zemin sağlaması Yerebatan Caddesi'nin gelişiminde önemli olsa da temel atma ve meyil vermeye dayalı altyapı tesislerinin döşenmesi gibi konularda zorluk çıarıyordu. 1894 senesinde, Ayasofya Rüştiyesi binası için mahallede münasip bir arsanın belirlenmesi kapsamında hazırlanan bir rapor, mahallenin zemini ve alt yapı olanakları hakkında dikkat çekici gözlemlerde bulunmaktadır. Yerinde yapılan keşif sonucuna göre, hane sarnıcın üzerine tesadüf etmekte ve zemin üzerinde yaklaşık 1 metre kalınlığında toprak tabakası bulunmaktaydı. İçerisindeki çamurun kalınlığı büyük olasılıkla sütun başlıklarına kadar ulaştığından sandalla gezerek tonoz ve kemerlerin sağlamlığını tetkik etmek imkânı bulunamamıştı. Ayrıca, zemin bina yapımına uygun olsa bile kanalizasyon gibi meyil vermeye dayalı diğer alt yapı tesislerinin yapımına müsait değildi. ${ }^{51}$ Okul binası için Yerebatan Caddesi üzerinde, Şengül Hamamı Yokuşu köşesinde bulunan Hakkı Paşa’nın konağı satın alındı. ${ }^{52}$ Bu yapı sarnıç üzerinde değildi. Eğimin başladığı eşikte olmasından dolayı kanalizasyon sorununun çözülebileceği düşünülmüş olsa gerek.

1892 tarihinde otuz kadar mahalle sakini, lağımları olmamasından dolayı çöplerin mahalle içerisinde bulunan çukurlarda toplandığı ve bu durumun kirlilik yarattığından şikâyet eden bir arzuhal sunarlar. Bu meseleye ek olarak, helalar için kazılmış kuyulardan sarnıca kirli su karıştığı da dile getirilir. ${ }^{53}$ Sarnıç temizlense dahi üzerine kanalizasyon yapılmadığı müddetçe sızıntının önüne geçilemeyeceği açıktır. Ayrıca 1857 tarihli bir karara atıfta bulunularak suyolları ve sarnıçlar üzerindeki deliklerin üzerinin kilitli bir demir kafesle kapatılması gerektiği belirtilir. ${ }^{54}$ Sarnıç üzerindeki bacaların tamamen mühürlenmesinden uzak durularak sarnıçlar içerisinde hava cereyanının sağlanması amaçlanır. ${ }^{55}$

Hıfzıssıhha Komisyonu bir rapor hazırlayarak, sarnıçtaki suyun kirli olduğunu ve temizlenmesinin aşırı masraf ve işgücüne tabi olduğunu belirtir. Sarnıç, eğer işlevini devam ettirecekse, suyun, demir borularla getirilmesi gerektiğini bildirmesine rağmen, tavsiyesi sarnıç içerisindeki suyun kullanılmaması ve mahallenin münasip yerlerine çeşmeler yapılması yönündedir..$^{56}$ Şehremanetinin hazırladığı başka bir raporda ise sarnıcın sadece Kırk Çeşme Suyolları'ndan su tedarik ettiği belirtilir. Eğer mahalleye çeşme yapilacaksa, çeşmelere, mecburen Halkalı Suyolları'ndan tahsisat yapılacağı ve bu durumun yükselti farkı nedeniyle Topkapı Sarayı'nın suyunu azaltacağına dikkat çeker. Rapor, sarnıçla ilgili şu gözlemlerde bulunur: Sarnıç yerin altındadır ve Ayasofya Meydanı’nda Sebzeci Sokağı’ndan Esad Efendi

50 Hafız Hüseyin Ayvansarayi, The Garden of the Mosques, çev. Howard Crane (Leiden: Brill, 2000), 51.

51 BOA, MF.MKT. 201/20 vrk. no. 2 (15 Nisan 1310 [27 Nisan 1894]).

52 BOA, MF.iBT. 39/39 vrk. no. 1 (18 Safer 1312 [27 Ağustos 1894]); BOA, MF.iBT 49/82 vrk. no. 1 (18 Ramazan 1313 [3 Mart 1896).

53 BOA, DH.MKT. 1976/84 vrk. no. 1 (12 Temmuz 1308 [24 Temmuz 1892]); BOA, DH.MKT 1994/15 vrk. no. 1 (12 Ağustos 1308 [24 Ağustos 1892]).

54 BOA, A.MKT.MHM. 594/36 vrk. no. 6 (28 Zilhicce 1313 [10 Haziran 1896]).

55 BOA, A.MKT.MHM. 594/36 vrk. no. 11 (8 Zilkade 1315 [31 Mart 1898]).

56 BOA, A.MKT.MHM. 594/36 vrk. no. 2 (22 Zilkade 1311 [27 May1s 1894]). 


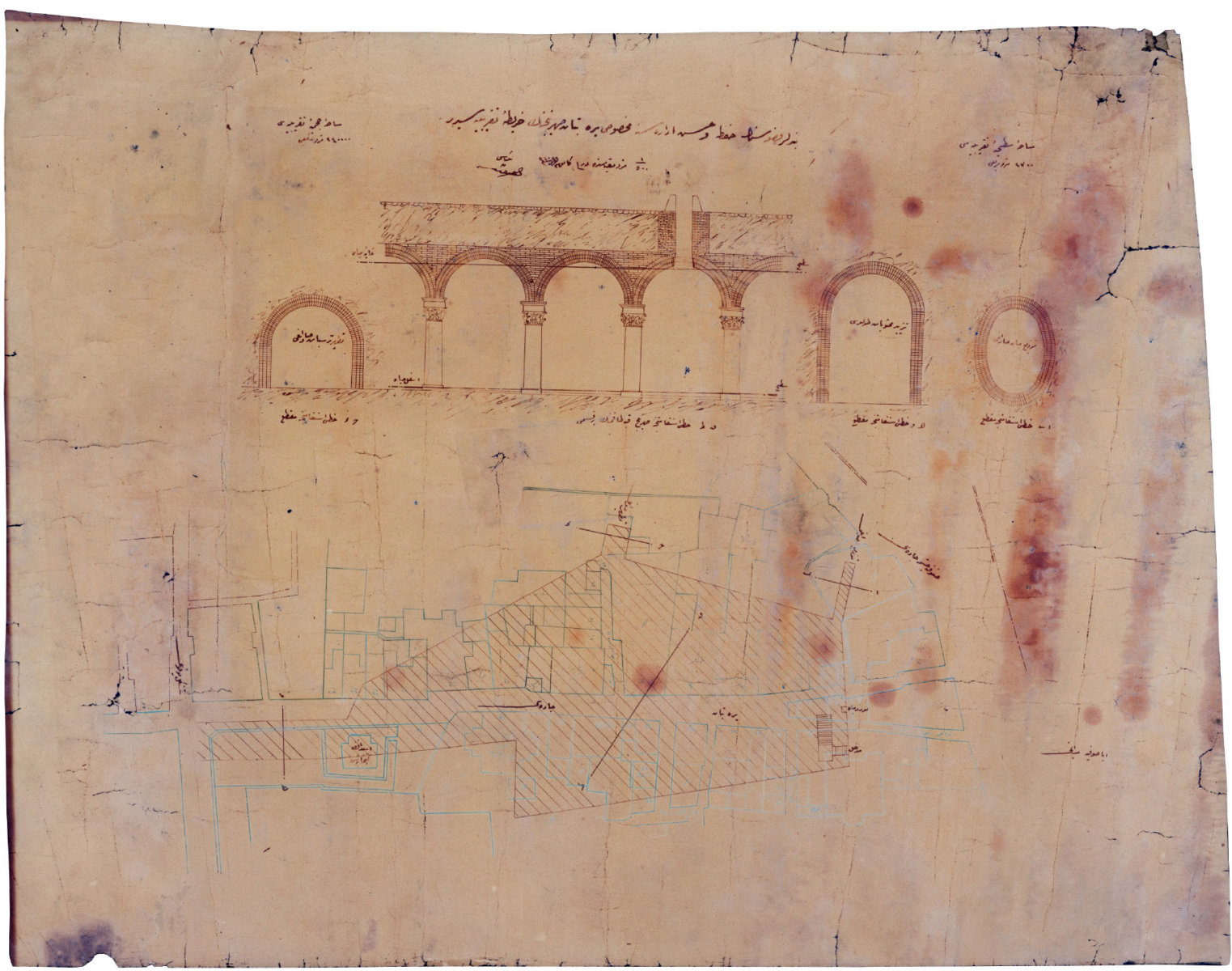

Kütüphanesi’ne doğru uzanmaktadır. Üzeri tonozla örtülü, $2.700 \mathrm{~m}^{2}$ büyüklüğünde bir alana yayılmış ve $240.000 \mathrm{~m}^{3}$ hacmindedir. Sarnıca gelen su, yaklaşık $7 \mathrm{~m}$ yükseklikten sarnıca akmaktadır. ${ }^{57}$ Söz konusu rapor, yapılması düşünülen çeşmelerden birisinin kesiti ve sarnıçtan istifade eden mahalle sakinlerinin bir listesini de ihtiva etmektedir. Listedeki isimler ağırlıklı olarak tüccar, memur, doktor gibi mesleklere sahip Müslümanlardır. Olasılıkla bu çalışmaların uzantısı olarak, sarnıçta kemerin delinmiş yerini, çamurun temizlenmesi için açlacak tünellerin istikametini, çamur biriktirme savaklarının kesitini ve sarnıcın mahalledeki oturumunu resmeden bir başka plan çizilir.

1893 yılında Forchheimer ve Strzygowski'nin yayınladıkları Yerebatan planının ${ }^{58}$ bir sene sonrasında Binbaşı Safvet (?) tarafından hazırlanan plan, 1/50o ölçeğindedir (şek. 2). 1846 tarihli planın (şek. 1) aksine Osmanlı ölçü birimi zirâ yerine metraj hesabı kullanılmıştır. Sarnıçtaki çamurun temizlenmesi için üç adet temizleme savağı ve savakların mahalleden çıkış noktalarını resmetmektedir.

"T hattı istikâmetince sarnıcın kubbe takımının bir kısmı" başlı̆̆ı ile sunulan kesit (makta) ilginçtir. Kemerin bu kısmının gösterilme nedeni bacanın üzerine yerleştirilecek demir kafesle ilgili olmalıdır. Tuğla örgülü kemer, kilit taşını ortada hizalayarak dışarı doğru, tertipli bir şekilde zemine çıkmaktadır. Tasarımın bir uzantısı olduğu görülen bu delik, olasılıkla Petrus Gyllius ve diğer bütün seyyahların ziyaretlerinde tanık oldukları, mahalle sakinlerinin kovalarla sarnıçtan su çektikleri havalandırma deliklerinden biridir.

Şekil 2: "Bendler fazlasını depolayan Yerebatan Sarnıcı'nın haritasıdır." BOA, PLK.p. 1271

(Kânunuevvel 1310 [Aralık 1894]). 
Dikdörtgen planlı, sütun sıralarının ana hatlarıyla düzenli bir tertipte sıralandığı sarnıç tasarımında, havalandırma deliklerinin de simetrik olması beklenir. Ancak durum böyle değildir. Tonoz üzerindeki deliklerin hemen hepsi Yerebatan Caddesi'ne cepheli konutların altında ve düzensizdi. 1896 yılında, mahalle sakinlerinin kolera salgınları nedeniyle sarnıcı kullanamadıkları, mahallenin altında sarnıç olmasından dolayı kuyu kazamadıkları ve yangına müdahalenin güçleşmesinden duydukları endişeyi dile getirdiklerini görürüz..$^{59}$ Diğer şikâyetler bir yana bırakılacak olsa da, kolera salgınlarının sarnıca yönelik kapsamlı bir müdahaleyi gerektirdiği düşünülüyordu. Tonozda açılan deliklerden kovalarla çamurun çıkarılması mümkün olmayacağından, sarnıç içerisinden savaklar açılarak çamurun savaklara sürülmesi, oradan da denize akıtılması planlandı ${ }^{60}$ Bunun için ise üç adet savağın ve doğrultusunun kesiti, kemer üzerinde açılan bir delik, savakların mahalleden çıkış noktalarını gösteren ve onlara eşlik eden çeşitli notlardan oluşan plan hazırlandı. Bununla birlikte, temizleme çalışmalarının başlatıldığına dair bir belgeye rastlayamadım. Ancak, 1921 tarihinde sarnıcın mülkiyeti ile ilgili tartışmalar esnasında şeyhülislam, sarnıcın içerisindeki çamur temizlenirken Cağaloğlu tarafına bir duvar örüldüğü ve masrafların da hazine tarafından karşılandığından bahseder. ${ }^{61}$ Hazine diye bahsettiği, olasılıkla Evkâf Hazinesi’dir.

I. Birinci Dünya Savaşı yıllarına gelindiğinde, sarnıca elektrik tesisatı döşenerek giriş ücreti karşılı̆̆ı ziyaretçilere açıldı. Bu yıllarda, bir Alman denizaltından katlanır bir bot getirtildiği, Alman arkeolog Eckhard Unger'in bu botla sarnıcı gezdiği ve yapının ölçülerinin ilk kez alındığına dair yerleşik, ancak tartışmalı bir görüş bulunmaktadır. ${ }^{62} 1921$ tarihinde Reşid Beyzade vermiş olduğu bir dilekçede süreç hakkındaki hikâyeyi geliştirmektedir. Sarnıç girişinin, yaklaşık seksen senedir ailesine ait konağın içerisinde bulunduğunu ve savaş sırasında Alman mühendislerin sarnıca elektrik tesisatı döşediğini söyler. İtalyalı De Orani Apolonyo isminde bir şirketin Rus işçileri çalıştırarak çeşitli tadilatlar yaptığını ve sarnıcın içine bir de iskele kurduğunu ihbar eder. ${ }^{63}$ Böylelikle, sarnıcın mülkiyeti konusu tekrar su yüzüne çıkar. Polis ve Mühendis İbrahim Bey bölgeye giderek restorasyonu durdurur ve yapılan tahkikatta sarnıç girişini, Apolonyo şirketine, Ahmedpaşazade Nureddin isminde birisinin kiraladığı belirlenir. ${ }^{64}$ Konu Şehremaneti, Vakıflar ve Müze-i Hümayun arasında bir ihtilafa dönüşür. Evkaf Nezareti, sarnıcın Fatih Sultan Mehmed Vakfi'na; ${ }^{65}$ Şehremaneti, kale mahallerinin belediyeye ait olduğuna dair kararları emsal göstererek kendilerine; ${ }^{66}$ Müze-i Hümayun ise sarnıcın "asar-ı âtikâdan" olması münasebetiyle müzeye ait olduğunu iddia etmiştir. ${ }^{67}$ ihtilaf, sarnıcın belediyeye bağlanması ile çözülmüşs, sarnıç 1940 yılında ise Müzeler Müdürlügü̈’ne devredilmiştir. ${ }^{68}$

\section{Yerebatan'da Mahalle Dokusunun Oluşumu ve Sokak Düzeni}

On yedinci yüzyıl sonunda suriçi İstanbul kent mekânını biçimlendiren önemli değişimlerden biri divan üyeleri ve paşaların iktidar alanının gelişimine paralel olarak Divanyolu ekseninin de öneminin artmasıdır. Maurice Cerasi, Divanyolu isimli çalışmasında, on altıncı yüzyıl itibariyle divan üyeleri ve paşa konak ve saraylarının Hipodrom-Kadırga, Sultanahmet, Beyazıt, Süleymaniye, Bozdoğan Kemeri’nin kuzeyi ve Vefa'ya kadar olan geniş bir alanda yayıldığını ifade eder. ${ }^{69}$ On yedinci yüzyılın sonu ve on sekizinci yüzyılın başında divan üyeleri ve paşaların saray ve konakları ile Topkapı Sarayı arasındaki güzergâhın merkezinde yer alan Divanyolu’nun öneminin arttığını vurgular. Cerasi, Divan üyeleri ve paşaların haftada iki gün Divan'da toplanıp maiyetleri ile birlikte saraylarına dönüşünü yeni bir kültürel, simgesel ve biçimsel katman olarak tanımlar. ${ }^{70}$

\footnotetext{
59 BOA, ŞD. 787/13 vrk. no. 11 (29 Rebiülahire 1314 [7 Ekim 1896]).

60 BOA, Ș. $787 / 13$ vrk. no. $12(1896)$

61 BOA, BEO. $4698 / 352321$ vrk. no. 2 (26 Recep 1339 [5 Haziran 1921]).

62 Yücel, "İstanbul'da Bizans Sarnıçları II," 20; Semavi Eyice, "Yerebatan Saray1," Dünden Bugüne İstanbul Ansiklopedisi, c. 7 (İstanbul: Kültür Bakanlığı ve Tarih Vakf1), 503-504.

63 BOA, DH.i.UM. 19-15/1-44 vrk. no. 2 (1337 [1921]).

64 BOA, DH.i.UM 9-15/1-44 vrk. no. 13 (5 Kanunusani 1337 [5 Ocak 1921]).

65 BOA, BEO. $4676 / 350640$ vrk. no. 4 (12 Cemaziyelahire 1339 [20 Şubat 1921]).

66 BOA, BEO. $4676 / 350640$ vrk. no. 2 (1 Cemaziyelahire 1339 [9 Şubat 1921]).

67 BOA, BEO. 4698/352321 vrk. no. 3 (20 Teşrinisani 1337 [20 Şubat 1921]).

68 Müller-Wiener, İstanbul'un Tarihsel Topografyast, 284.

69 Maurice Cerasi, Divanyolu, çev. Ali Özdamar (İstanbul: Kitap Yayınevi, 2014), 89-9o.

70 lbid., 66.
} 
Yerebatan ve bitişiğindeki Cağaloğlu Caddesi, Divanyolu’na katılan önemli güzergâhlardan biridir. "Yerebatan Sarayı" isimlendirmesi bahsinde, bu ismin, Çatal Çeşme Sokağı'nda Bıyıklı Mustafa Paşa'nın inşa ettiği sarayı işaret ettiği, saray ve sarnıcın iki farklı yapı olduğundan bahsedilmişti. Yerebatan'da 1709'da çevre duvarları örülen ${ }^{71}$ ve 1720 başında Damat İbrahim Paşa'ya devredilen Bıyıklı Mustafa Paşa Sarayı bu katmanın en önemli odak noktasıdır. Saray, İbrahim Paşa'nın maiyeti ile birlikte devlet işlerini yürüttüğü bir mekândır. Örneğin, 1720'de katip odasında düzenledikleri bir toplantıda Mimarbaşı Mehmed Ağa, Kasımpaşa'da yaptığı dükkânlar hakkında bilgi verir. O dönem kaynaklarında Yerebatan, mescidin isminden dolayı Üskübî Mahallesi olarak anılmakta, ${ }^{72}$ sarnıcın girişi ise "Yerebatan mahalli" olarak tarif edilmektedir. Mahalle isminin Yerebatan olarak değiştirilmesi için on dokuzuncu yüzyılı beklemek gerekecekti.

Saray yerleşkesi, 1740 senesindeki Büyük Bâbıâli Yangını'nda yandı. ${ }^{73}$ Şem'dânî-zâde Fındıklılı Süleyman Efendi, İbrahim Paşa'nın ölümünden sonra terk edilen ve daha sonra tekrar Paşa Kapısı olan sarayın Şubat 1740'daki yangında önce hareminin, daha sonra ise harici kısımlar ile divan-hanesinin yandığını belirtir. Şem'dânî-zâde, yanan saray yerleşkesinin üzerine bir hamam ve mahalle inşa edildiğini şöyle ifade eder: "Yeni-hamam tesmiye olunan musannâ ve mülûkî hamamı binâ ve bâkîsine menâzil ihdâs olunub, mahâlle kılındı."74 Bahsi geçen hamam 1741'de yapımı bitirilen Cağaloğlu Hamamı'dır. Yeni tesis edilen konutlar ve mahallenin ne ölçüde, o dönemdeki ismi ile Üskübî Mahallesi içerisine nüfuz ettiğini tespit etmek zor. Ancak 1874 tarihli emlak kayıt defteri, birisi Soğuk Çeşme'de eski ahırların olduğu arazide, altısı mahallenin kuzeybatı sınırında, Cağaloğlu tarafında olmak üzere toplam yedi adet hane arsasını kayıt etmektedir. ${ }^{75}$ Yerebatan Caddesi'nin devamındaki Cağaloğlu Caddesi'nin oluşumunu tespit etmek ve iç bütünlüğü olan tutarlı bir analiz ortaya koymak şimdilik bir hayli zor. Ancak 1740’a kadar tören alaylarının, Paşa Kapısı olarak adlandırılan saray yerleşkesinden Topkapı Sarayı'na geliş gidiş güzergâhlarından biri Alayköşkü Caddesi, diğeri ise Divanyolu ve Ayasofya Meydanı'na açılan Yerebatan Caddesi'ydi. ${ }^{76}$

Yerebatan Sarayı’nın mahallenin kuzeybatı tarafına konumlandığı bilgisi mevcut olsa da avlusu ve ahırları gibi müştemilatının mahallenin kuzeyini çevrelediği; Çatal Çeşme ile Yerebatan Caddesi ve Divanyolu'nun kesiştiği noktada yer alan Milion Taşı arasındaki alana yayıldığını belirten birçok işaret bulunmaktadır. Örneğin, on sekizinci yüzyılın özellikle ikinci yarısından itibaren mahalleyle ilgili birincil kaynakların çoğunluğu artık sadrazamın atlarına tahsis edilmiş olan Yerebatan Sarayı ahırlarının tamir edilmesi ile ilgili olup, 1803 tarihli mahalle planında da Ayasofya Meydanı tarafındaki Dörtyol ağzındaki sarnıç girişinin kuzeyi "Yerebatan ahuru" olarak işaretlenmiştir (şek. 3).

Yerebatan Sarayı arsası I. Mahmud Kütüphane Vakfı'nın mülkiyetine geçmiştir. Bu nedenle vakıf, mahalle dokusunun oluşumuna müdahil bâni olarak öne çıktı. Ancak birbiri ardına gelen yangınlar mahalle dokusunu şekillendiren en önemli etkendi. 1755 Bâbıâli Yangını'ndan sonra saray arsasının bir bölümü terzilere tahsis edildi. Buradaki binalar 1779 senesindeki yangında yeniden yandı, dört sene sonra binaların yapımı ve I. Mahmud Kütüphane Vakfı adına kiraya verilmesi için mütevelliye izin verildi.77

Bir diğer yangın ise Arslanhane civarında haftancı esnafının sakini oldukları binaları yok etti. 1803 senesinde yangın nedeniyle ìstanbul'un çeşitli yerlerine dağılan ustaları belirli bir alanda toplamak için yer arayışına girildi. Yerebatan Mahallesi'nde terzilere ayrılmış iki arsanın haftancı esnafının yeni üretim merkezi olması kararı alındı ${ }^{78}$ Yer seçimi çalışmaları kapsamında sermimar Ibrahim Kâmi mahallenin ölçeksiz bir vaziyet planını hazırladı. ${ }^{79}$

71 BOA, D.BŞM. 1610/40 vrk. no. 2 (18 Rebiülevvel 1121 [28 Mayıs 1709]).

72 BOA, C.BLD. 5400 vrk. no. 1 (25 Ramazan 1132 [31 Temmuz 1720]).

73 Mustafa Cezzar, "Osmanlı Devrinde İstanbul Yapılarında Tahribat Yapan Yangınlar ve Tabii Âfetler," Güzel Sanatlar Akademisi Türk

Sanatı Tarihi Araştırma ve Incelemeleri I (1963): 356.

74 Şem'dânî-zâde Fındıklılı Süleyman Efendi, Müri'i't-Tevârih, haz. Münir Aktepe, c. 1 (İstanbul: İstanbul Üniversitesi Edebiyat Fakültesi

Matbaas1, 1976), 95.

75 BOA, ML.VRD.d. 3797 vrk. no. 1a-12a (27 Cemaziyelevvel 1291 [21 Temmuz 1874]).

76 Nitekim sarnıç restorasyonu ile ilgili olan ilk tarihi kayıt Yerebatan Sarayı'ndan Ayasofya Camii'ne giden "târik-i 'amme tarafı ziyade

ayrulub" ifadesi ile başlar. Bkz. BOA, MAD. 8947 s. 153 (11 Safer 1135 [21 Kasım 1722]).

77 BOA, TS.MA.e. 830/7 vrk. no. 1 (9 Zilkade 1197 [6 Ekim 1783).

78 BOA, C.ML. 21757 vrk. no. 2 (17 Cemaziyelevvel 1218 [4 Eylül 1803]).

79 BOA, C.ML. 21757 vrk. no.1 (1803). 


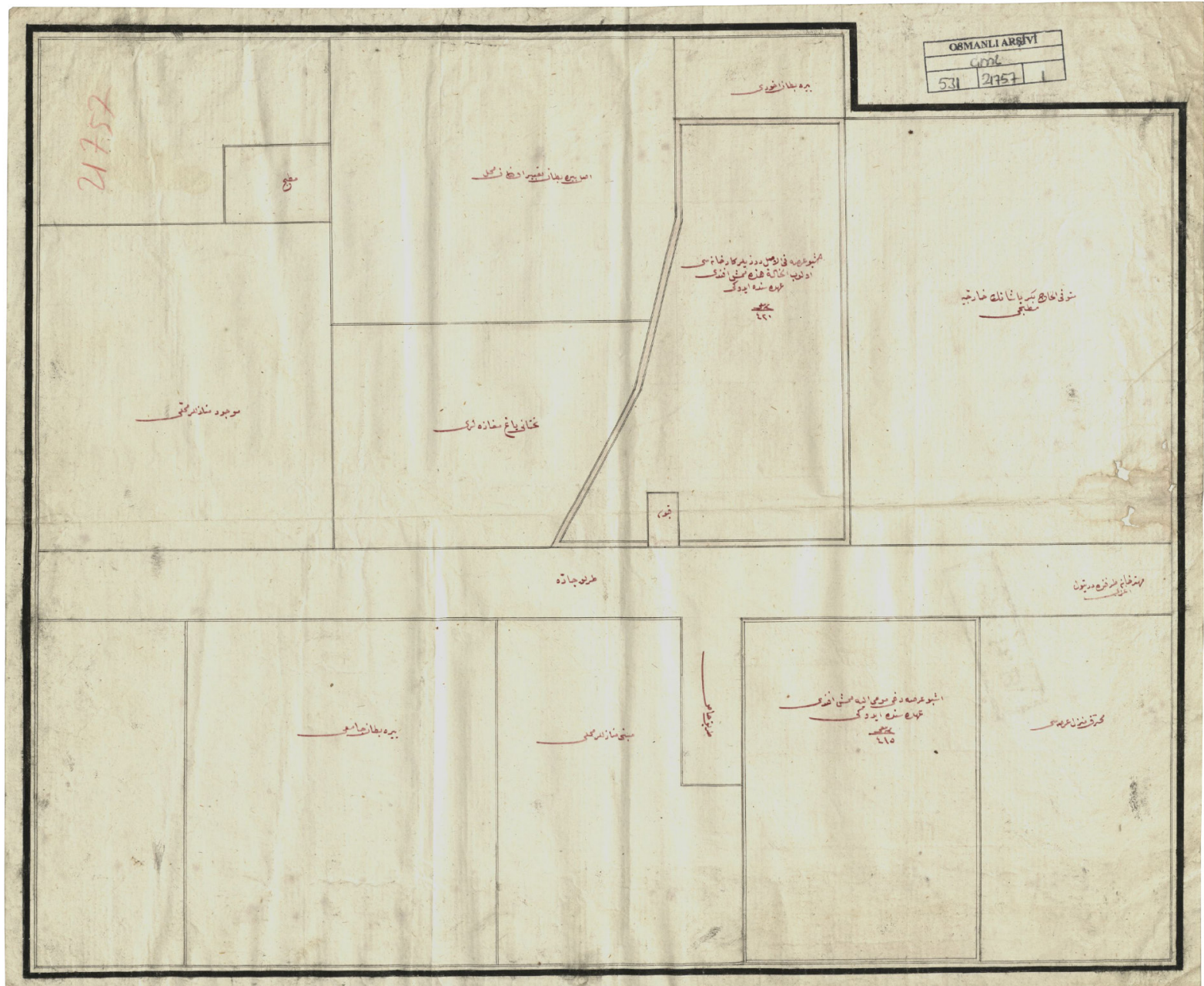

Şekil 3: Yerebatan'da haftancı esnafına tahsis edilen arsa ve çevresinin planı. BOA, C.ML 21757 (1803).
Plan, caddenin kuzeyinde bulunan arsanın etrafını duvarla çevrili olarak göstermektedir. Burada, arsadan caddeye geçişte bir de kapı bulunmaktadır. Diğer parsellerden hiçbiri etrafı duvarla tahdit edilmiş olarak gösterilmemiştir. Plana göre arsalar, Yerebatan Caddesi üzerinde karşılıklı olarak konumlanmıştır. Caddenin güneyindeki arsanın iki tarafı konut alanıdır; bir yanı-olasılıkla yangın nedeniyle harabe halindeki-konutlar ve bir yanı cadde ile sınırlandırılmıştır. Caddenin kuzeyi ise sarnıç girişi hizasında bulunup Bekir Paşa’nın dış mutfağı, Yerebatan ahırları ve cadde ile çevrelenir.

Mahallenin sokak dokusu ve yapı adalarını gösteren daha eski bir çizime rastlanmaması nedeniyle söz konusu planın özel bir önemi bulunmaktadır. Plan, mahalle sahnesini sürekliliği olmayan; farklı işlevlerin mahallenin belirli yerlerine kümelendiği bir mekân olarak resmeder. Yerebatan Caddesi mahallenin merkez doğrultusudur: Cadde, mahalleyi boyuna düz ve kesintisiz bir hat boyunca ikiye ayırır. Caddenin Ayasofya Meydanı tarafı "Mehterhâne tarafında Dörtyol ağzı" notu ile gösterilir. "Asl Yerebatan tâbir olunan mahal" diye işaretlenen arsa, sarnıç girişinde ve kuzeydedir. Milion Taşı hizasındaki alan "Yerebatan ahuru" olarak belirlenir. Burası, Bıyıklı Mustafa Paşa Sarayı'nın mahalleyi kuzeyden çevreleyen uzantısıdır. Sarnıç girişi kısmında ve cadde ile komşuluğu olmayan, olasılıkla bir konağın mutfağına işaret eden küçük bir alan bulunmaktadır. Caddenin kuzeyinde, giriş ve Çatal Çeşme Sokağı arasında sırasıyla Ebubekir Paşa'nın dış mutfağı, etrafı duvarla çevrili ve caddeye bir kapı ile açılan terziler karhanesi, yağ depoları ve "mevcud menziller mahalli" olarak işaretlenmiş yapı grupları alanı bulunmaktadır. Bu ada, caddenin kuzeyindeki büyük parseller içerisine doğru girmiş tek konut alanıdır. Parselleri birbirinden ayıran sokakların olmayışı, caddenin kuzey mahal dokusunun ana karakteristiğidir. Bununla birlikte, söz konusu parsel dizisinde olan Muhterem Efendi Türbesi'nin işaretlenmemesi ve türbeye giden sokağın belirtilmemesi göz önünde bulundurulmalıdır. 
Art arda sıralanmış konut adaları ise caddenin güney dokusunun baskın özelliğidir. Dörtyol ağzından başlayarak yanmış konutlar, Memiş Efendi arsası, çıkmaz sokak, mevcut hane arsaları ve Yerebatan Camii sokak üzerine dizilidir. Planın, vaziyeti ne derece doğru gösterdiğini belirlemek güç olmakla birlikte, "târik-i hâs" olarak işaretlenmiş, yapı adasının içine doğru yönelmiş bir çıkmaz sokak vardır. Burası caddeyi dikine kesen tek sokaktır.

Ahırlar, haftancı esnafının yerleştiği arsa ve olasılıkla bakımsız konakların mutfak mahalli arasına girmiş konutlar, caddenin kuzey kısmındaki parçalı ve sürekliliği olmayan mahalle dokusunun özelliğidir. Güney kısmında, cadde üstünde dizili yapı grup adaları ise kısmi bir bütünlük arz eder. Bu kısımda artık parseller hacimsel olarak küçülmüş; büyük parselin bölünmesi aşamasındaki zorluklar aşılmıştır. Bu nedenle kentsel gelişim vaat eden Üskübî Mescidi sırasındaki arsalar, sarnıç girişi hizasındaki arsalara nispeten daha değerliydi. Bu durum şöyle anlatılır: "...ol semtlere nazaran değer bahası erbâb-1 vukūfdan istihbâr oldundukda Yerebatan tarafında olan arsanın beher zirấı bahâya üçer guruşdan bin iki yüz altmış guruş ve mukâbilinde kâin arsanın şerefiyeti cihetiyle beher zirâ'ı bahâya beşer guruşdan..." ${ }^{\prime \circ}$ Mescit tarafında yer alan arsaların yaklaşık on metre uzağında, hemen karşısındaki arsalara göre neredeyse iki katı değerli olması bir hayli ilginçtir. Sarnıç girişi hizasında bulunan ahırların yaydığı koku, yağ depolarının varlığı ve büyük parsellerin henüz küçülme eşiğine girmemiş olması gibi açıklamalar yapmak mümkündür. Belki de restorasyon örneklerinde görüldügüü üzere sarnıç girişi hizasındaki kısmi de olsa dönem dönem çöken üst örtünün yaydığ 1 korkudur.

Maurice Cerasi, kent mekânında hem bani, hem de mimarın "ayrılık ya da homojenliği bir a priori ilke sorunu olarak empoze etmeyip, zıtlıkların oyunundan ve bundan çıan çok seslilikten aşikâr bir zevk" "sı aldıklarını ifade eder. Bu nedenle mahalle özelinde birbirine bitişik saray avluları ve parsellerin içerisine doğru yapı grupları adaları nüfuz edebiliyor; saray ve konak mutfak alanlarının arasına bir dikim atölyesi yerleşebiliyor ve esnaf gruplarının mahalleye girişinde bir sakınca bulunmuyordu. 1803 tarihli mahalle planında, gösterilen büyük parseller içerisine doğru nüfuz etmiş menzil alanları, yani grup adaları, yüzyılın sonuna gelindiğinde mahalledeki parsellerin hacimsel olarak küçülmeye başlamasının habercisidir. Yüzyılın sonlarında dik açı ile caddeyle bütünleşen sokaklar aşamalı olarak ortaya çıktı. Toprak Sokak ve Şeftalü Sokağı, Yerebatan ahırlarının işgal ettiği arsa üzerinde kentsel dokuya katıldı. Daha sonraki mahalle dönüşümü aşamalarında da Yerebatan Caddesi, mahalle dokusunda morfolojik ve sivil işlevlerin yüklendiği merkez olarak kalmaya devam etti. On dokuzuncu yüzyıldan önce inşa edilen cami, gelen geçenin su ihtiyacının karşılanması maksadıyla yapılmış sebil, yüzyıl ortasında tesis edilen kütüphane ve yüzyılın sonunda yapılan okul binası cadde üzerinde, erişimin en kolay olduğu parsellerdedir. Bu dönemde artık parseller küçülmüş, Yerebatan Caddesi'nin her iki yanına orta büyüklükteki parsel dizileri sıralanmış, caddeyi dikine kesen sokaklar yerlerini işaretlemiştir. On dokuzuncu yüzyılın başında, farklı işlevler mahallenin farklı yerlerinde kümelenmişti; dönüşümün bir sonucu olarak mahalle morfolojisinde bir süreklilik ve doku benzerliği aranacaksa yüzyılın ortalarını beklemek gerekecekti. Bunun izlerini, 1874 senesinde hazırlanan mahallenin emlak defterinde yakalayabiliriz.

\section{Emlak Tahriri'nde Yerebatan Mahallesi}

Soğuk Çeşme Caddesi'nden geçen gaz borularının Cağaloğlu Caddesi'ne bağlanması ve mahalle

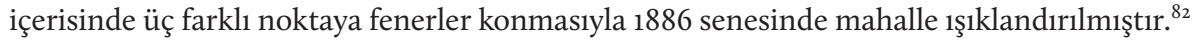
Konuyla ilgili yazışmalar, "şerefli mevkilerden" olması nedeniyle mahalleyi ı̧̧ıklandırmayı da öncelikli bir iş olarak belirler. ${ }^{83}$ Bunda mahallenin Topkapı Sarayı ve Bâbıâli'ye yürüme mesafesinde olması; Divanyolu, Soğuk Çeşme, Alayköşkü ve Cağaloğlu caddeleri gibi kentin ana yollarının bitişiğinde konumlanması etkendir. Mahallenin toplumsal içeriğini dini, etnik, mezhepsel veya lider asabiyeti değil merkezi bürokrasiye olan fiziksel yakınlık belirledi; mahalle sakinleri, bürokrat kökenli ailelerden oluşuyordu. 
On sekizinci yüzyıl sonunda saraya nazır konumda olan yapı adalarında kat sınırlaması olduğu ve konutların ahşap olması nedeniyle yangınlardan doğrudan etkilendiği belirlenmişti. Ancak bu bilgiler, mahalle morfolojisi ve toplumsal yapı hakkında genel bir çerçeve sunmaktan uzaktır. Bununla birlikte 1874 tarihli emlak tahrir defteri mahalledeki sokaklar, haneler, kiracılar, mülkiyet durumu ve mahallenin sınırları hakkında zengin detaylar ve bütüncül bir çerçeve sunar. ${ }^{84}$

1874 Yerebatan emlak tahriri, mahalledeki konutlarm emlak vergilerini belirlemek amacıyla hazırlanmıştır. Yapının cinsi, eski ve yeni numarası, yapı malzemesi, müştemilatı, sınırları, sokağı, kiracısı, mülk sahibi ve vergisi hakkında bilgileri detaylandırır. Kent tarihi çalışmalarında müstesna bir yeri olan bu emlak defterlerinin Yerebatan Mahallesi özelinde eksikliklerinden biri yapıların büyüklügü konusunda bilgi vermemesidir. Tahrir, mahalleyi Yerebatan Caddesi ile ikiye ayırır. Şengül Hamamı Yokuşu, Karanlık Sebzevatçı, Soğuk Çeşme, Çatal Çeşme sokakları komşu mahalleler arasındaki sınırı belirler. Toprak, Muhterem Efendi, Salkımsöğüt ve Şeftalü sokakları mahalle içerisindeki sokaklardır.

Ayasofya Meydanı ve Cağaloğlu arasında, güneybatı ve kuzeydoğu doğrultusunda Yerebatan Caddesi bulunur. Cadde, Ayasofya Meydanı tarafındaki çıkışta çatallanarak iki dar koldan Divanyolu'na bağlanır. Bu kollardan biri sarnıcın girişi tarafındaki Karanlık Sebzevatçı Sokağı'dır. Tahrir, dar ve belli belirsiz olan diğer kolu Soğuk Çeşme Caddesi'nin uzantısı olarak yorumlar. Burada Ayasofya Camii'ne cepheli dükkân sırası Yerebatan ve Soğuk Çeşme Caddesi ile birleşerek kent dokusunun içine yerleşir. Lala Hayreddin ve Ayasofya-1 Kebir Mahalleleri ile komşu olan caddedeki emlâkın bazısı o mahallelere yazılmıştır. Yerebatan Mahallesi tarafında sebzeci, kasap, berber gibi dokuz dükkân ve bir de kahvehane bulunmaktadır. Berber dükkânı haricinde yapıların hepsi ahşap ve çoğunluğu tek katlıdır. Soğuk Çeşme Caddesi ile Yerebatan Caddesi'nin kesiştiği köşede üç katlı ve on iki odalı bir konak bulunur.

Yerebatan Caddesi, mahalleyi boyuna ikiye bölen en geniş ve uzun caddedir. Mahalle içerisindeki diğer sokaklar bu caddeye bağlanır. Ayasofya Meydanı tarafından girişle başlayan tahrir, cadde boyunca otuz dört hane, bir cami ve sebil, dârülmuallimât, dükkân, kütüphane ve bir de odayı kayıt eder. Hanelerin hepsi ahşap ve üçü bahçelidir. Cami kâgirdir ve banisi Üskübî İbrahim Efendi'dir. Tavşani İbrahim Ağa ise sebilin banisi olarak kayıt edilir. Caminin sırasında üç katlı, on üç odalı ahşap bir hane Dârülmuallimât okuluna tahvil edilmiştir. Caddede bulunan diğer kâgir yapı ise tek katlı Esad Efendi Kütüphanesi'dir.

Yerebatan Caddesi’nin Ayasofya Meydanı'na doğru çıkışta, Milion Taşı tarafına ayrılan kolu Karanlık Sebzevatçı Sokağı'dır. Bu sokakta toplam dört hane ve iki konak bulunur. Konaklar olasılıkla Ayasofya Meydanı cepheli ve caddenin Divanyolu ile kesiştiği köşededir.

Yerebatan Caddesi'ni dikine kesen Şeftalü Sokağı'na beş ahşap hane dizilmiştir. Toprak Sokak'ta ise aynı yapı özelliklerini gösteren üç adet iki katlı hane bulunur. Muhterem Efendi Sokağı Yerebatan Caddesi'ni dikine keser; altı hane, iki hane arsası ve bir de Muhterem Efendi'nin türbesi bulunur.

Bu yapı adasının karşısında, Şengül Hamamı yokuşu tarafında Yerebatan Sokağı ile anılan başka bir sokak bulunur. Bu sokak, Yerebatan Caddesi'ni dikine kesen ve Şengül Hamamı Sokağı ile birleşen Salkım Söğüt Sokağı olmalıdır. Zira, tahrir Salkım Söğüt’ten bahsetmez. Bu sokakta altı ahşap hane bulunur ve beşi iki katlıdır.

Şengül Hamamı Yokuşu Sokağı mahalleyi güneydoğudan çevreler, Lala Hayrettin Mahallesi'nden ayırır. Altı hane, bir ahır, bir de bahçe bulunmaktadır. Sokak boyunca yer alan yapıların çoğunluğu Lala Hayrettin Mahallesi sınırları içerisindedir. Çatal Çeşme Sokağı, Salkım Söğüt Sokağı'na paralel uzanır ve mahalleyi Cağaloğlu tarafından ayırır. Bu sokakta mahalle sınırları içerisinde gösterilen bir bahçe ve iki hane bulunmaktadır. 
96 Böylelikle mahallede konaklar ve hane arsalarıyla birlikte toplam yetmiş hane, dokuz dükkân, bir kahvehane, cami, sebil, türbe, kütüphane ve dârülmuallimât bulunmaktadır. Berber dükkânı, kütüphane ve cami dışındaki bütün yapılar ahşaptandır. Perakende satış noktaları mahalle içerisinde değil; Soğuk Çeşme Caddesi tarafında yer alır. Tek katlı yapılar bu kısmın özelliğidir. Çift katlı yapılar mahallenin genelinde olmakla birlikte daha çok Şeftalü ve Yerebatan (Salkım Söğüt) sokaklarında yoğunlaşır. Tahrirde konak olarak tabir edilen yapılar esasında ölçek olarak yanındaki hanelerden çok da büyük değildir. Sokakların birleştiği köşede konumlanmaları nedeniyle hane değil konak olarak isimlendirilirler.

Sarnıcın vakıf mülkiyetinde olmadığı ve bu nedenle sarnıç onarımlarını finanse etmede çıkmaza düşüldüğünden bahsedilmişti. Bununla birlikte sarnıç üzerindeki konutlar Rahime Hatun, Hacı Beşir Ağa, Ayasofya-1 Kebir ve I. Mahmud vakıfları gibi birçok vakfın mülkiyetindedir. Mahallede bulunan sıra dükkânlar Hacı Beşir Ağa Vakfı'na aittir. I. Mahmud Vakfı'na ait terzihanelerin yerini artık haneler almıştır.

1908 tarihinde Yerebatan Caddesi'nin girişinin genişletilmesi ve ıslah edilmesi çalışmaları kapsamında Karanlık Sebzevatçı sokağında yer alan ve Ayasofya Meydanı'na nazır hane tahliye edildi ve yıkıldı. ${ }^{85}$ Yine Karanlık Sebzevatçı Sokağı'nda bulunan bir hanenin yüzü tıraşlandı. ${ }^{86}$ 1915 tarihinde ise mahallenin sokaklarını ve hanelerini düzenleyen son müdahale gerçekleşti. Yangından sonra hazırlanan 1/500 ölçekli 'Yerebatan harik mahalli haritası' ve plan notları müdahalenin kapsamını anlamak açısından önemlidir (şek. 4). Yangın, Şengül Hamamı Yokuşu ile Üskübî Camii'nin arasındaki bölgeyi yok etmiştir. Silinen hane arsalarına "tarla kaidesi"/ ızgara plan uygulanmıştır. Bu kapsamda Yerebatan Caddesi'nin camii tarafında bulunan sokak çizgisi geriye çekilmiş, Üskübî Camii arsasının bir kısmı yola dahil edilmiş ve haneler bölünmüştür. Haritaya göre Esad Efendi Kütüphanesi sırasında yer alan yapılar artık kâgir olmuş ve yangından etkilenmemiştir. ${ }^{87}$

Şu aşamada sarnıcın kemerlerinin mahallenin hangi bölgelerinde delinmiş olabileceği sorusu akla gelmektedir. Bu sorunun cevabı 1895 senesinde, sarnıçtan istifade eden hanelerle ilgili hazırlanan rapor ve emlak defterinde hanelerin numarasının karşılaştırılmasında yatmaktadır. Örneğin, emlak defterinde dârülmuallimât olarak kayıt altına alınmış 31 numaralı, üç katlı ve on üç odalı ahşap hane ${ }^{88} 1895$ tarihli listedeki "Hakkı Paşa muahaaran Maarif Nezaretinden bil-muayene Ayasofya Merkez Rüştiyesi” olduğu notuyla verilir. ${ }^{89}$ Sarnıçtan istifade edenler listesinde bulunan toplam yirmi beş haneden sadece biri Soğuk Çeşme Sokağı'nda olasılıkla sarnıcın girişinde bulunur. Kalan yirmi dört hanenin hepsi Yerebatan Caddesi üzerinde bulunan hanelerdir. Bu durum, sarnıcın örtüsünün daha çok Yerebatan Caddesi boyunca dizilen haneler altında delinip tahribata uğradığı sonucunu verir.

Defter, dini bir yapıyı değil, caddeyi mahallenin merkezine konumlandırmakta; mahallenin ilk önce cadde boyunca büyüdüğü ve etrafındaki sokakların caddeye eklenmesiyle mahalledeki sokak düzeninin şekillendiği izlenimini vermektedir. 1803 senesinde haftancı esnafının mahalleye yerleşmesi amaciyla çizilen plandaki mekânsal dizilimde de cadde mahalle merkezini biçimlendiriyor ve homojen olmasa da parseller cadde üzerinde sıralanıyordu.

\section{Sonuç}

Aldo Rossi'nin locus kavramını "belirli bir yer ile onun üzerinde bulunan yapılar arasındaki ilişki” olarak tanımladığı belirtilmişti. Yer, olay ve temsil arasında bir bağlantı kuran Rossi, mimari ve biçimin yer üzerine nakşedildiğini söyler. Sınırları belirli bir yerdeki yapılar yok olabilir veya işlevleri değişebilir ancak bir referans noktası olarak kentsel bağlamda varlığ devam eder. Bu anlamda, anıtsal bir yapı olarak Yerebatan Sarnıcı bulunduğu mahallin en önemli referans noktasıdır. Bizans döneminde İstanbul'un birinci ve ikinci tepeleri arasındaki vadinin, yaz aylarında su ihtiyacını karşılamak için ana kaya üzerinde yapılan sarnıç, Osmanlı

85 BOA, DH.MKT. 2693/18 vrk. no. 1 (2 Zilhicce 1326 [26 Aralık 1908]).

86 BOA, DH.MKT. 2751/86 vrk. no. 1 (27 Zilhicce 1326 [20 Ocak 1909]).

87 Atatürk Kitaplığı, Hrt 5378 pafta no. 1 (16 Mart 1331 [29 Mart 1915]).

88 BOA, ML.VRD.d. 3797 vrk. no. 1a-12a (27 Cemaziyelevvel 1291 [21 Temmuz 1874]).

89 BOA, A.MKT.MHM. 594/36 vrk. no. 8 (8 Recep 1312 [19 Ocak 1895]). 


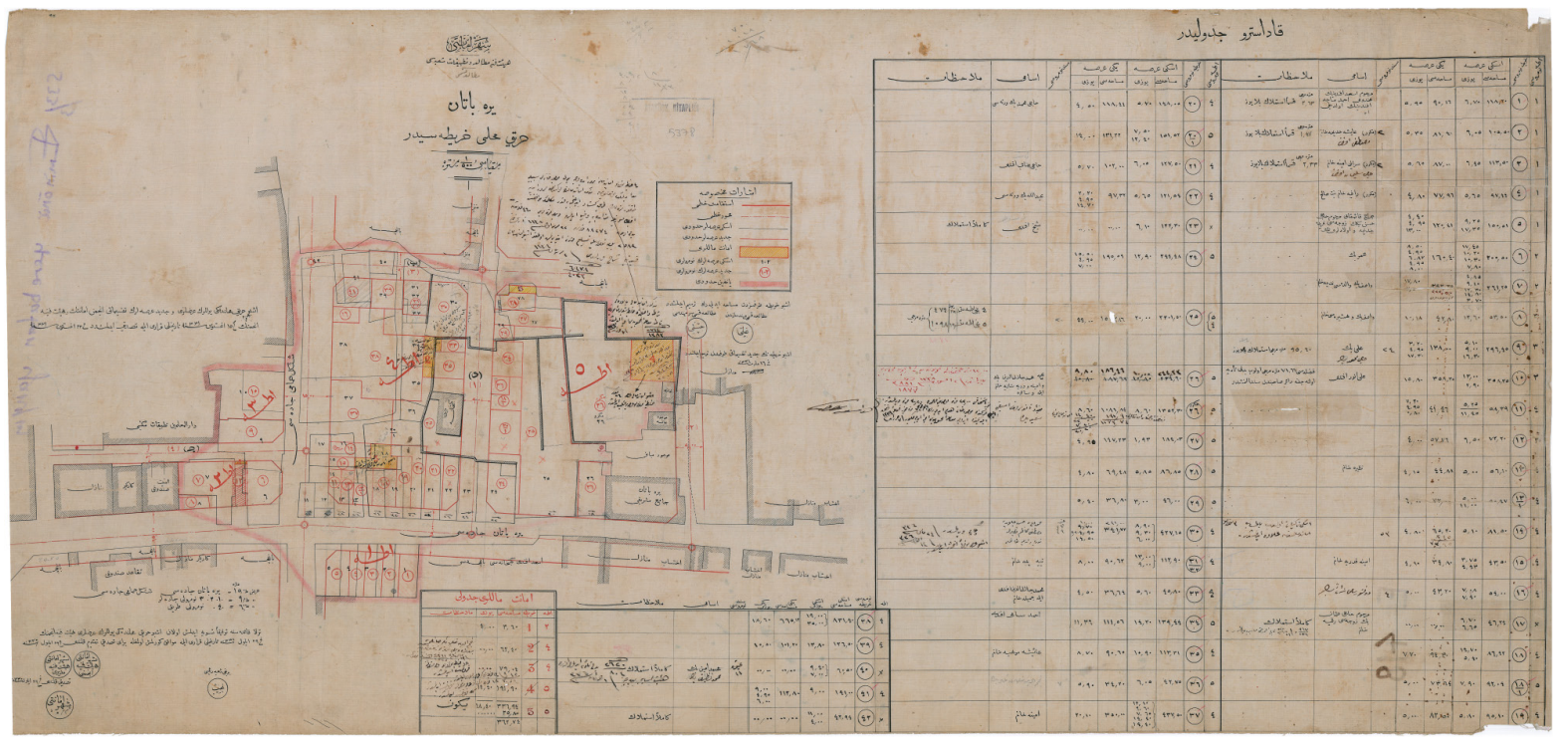

Şekil 4: Yerebatan hârik mahalli haritası. Atatürk Kitaplı̆̆ı, Hrt 5378, 29 Mart 1915. döneminde, kentin ana arterinin hemen yanı başındaki mahallenin zemini oldu. Mahallenin kendisi ve diğer önemli yapılarının da referans noktası oldu.

Dilbilimsel olarak locus'un Türkçe karşılığı olan mahal, Osmanlı bağlamında hemen her durumda imar edilmemiş boş arsayı tarif eder. Kentsel dokuda mahalden mahalleye geçişi Şem'dânî-zâde Findıklılı Süleyman Efendi'nin Paşa Kapısı yangını anlatısı ve sonrasında gelişen olaylarda izleyebiliriz. Bu anlatıya göre, Yerebatan'da bulunan saray yerleşkesi 1740'ta yandı ve arsası üzerinde "eser-i binâ kalmayınca" yok oldu. Boş arsalar üzerine yeni bir hamam ve "bâkîsine menâzil ihdâs olunub, mahâlle kılındı." Bu anlatıya göre bir mahallin mahalle olarak adlandırılması için bir referans noktası, Cağaloğlu Hamamı ve konutların yapımı yeterlidir. Yerebatan Sarnıcı'nın konumu ve kapladığı alan bilinmektedir. Bundan dolayı sınırları ve iç bütünlüğü olan bir Osmanlı mahallesinin mimari ve morfolojik niteliğini analiz etme adına önemli fırsatlar sunmaktadır. Bu makale, sarnıçta yapılan onarımları ve sarnıcın üzerinde inşa edilen mahallenin mimari ve morfolojisini konu edinmiştir.

Restorasyon masraflarının yüksek olması, sarnıcın içinin ışıklandırılmaması ve mevcut çamurun çalışmayı zorlaştırması Osmanlı dönemindeki restorasyonların niteliğini belirleyen önemli etkenlerdi. Osmanlı dönemi onarımlarının sarnıcın giriş kısmı hizası ve Esad Efendi Konağı avlusuna denk gelen kuzeybatı köşesinde yoğunlaştı̆̆ını söylemek doğru olacaktır. Restorasyonlarla ilgili ulaşılan ilk kayıt 1722 tarihlidir ve tarif edilene göre Yerebatan Caddesi'nin Ayasofya tarafı çıkışındaki yolun çökmesi kaynaklıdır. 1765 ve 1790 senelerindeki müdahaleler de bu kısım civarındadır.

Sarnıcın kuzeybatı köşesinde yıkılan ve 1805'te bir set duvarı ile kapatılan kısım 1846 tarihli sarnıç planında açık olarak gösterilmiştir. Sarnıcın daha eski planlarına rastlanmamıştır. Tarih belirtilmemesine rağmen, plan notlarındaki detayların o dönem yazışmalarındaki ifadelerle uyumluluğu nedeniyle planın tarihi 1846 olarak belirlenmiştir. Plan notlarındaki detaylar sarnıcın büyüklügüu, su tutma kapasitesi, içerisindeki çamurun miktarı, yıkılan taşıyıcı ve örtü hakkında bilgi vermektedir. Bu nedenle sarnıç ölçülerinin ilk kez bu dönemde hesaplandığını söylemek yanlış olmaz. 1894 tarihli plan yeraltı sarnıçlarında çamurun temizlenme metotlarından birisini göstermesi bakımından önemlidir ve bu amaçla yapılan çalışmaların bir özetini sunar. Plan, delinen kemer ve savakların, tünellerin istikameti ve sarnıcın mahalle içerisine oturumunu resmeder.

Sarnıç, örtüsü üzerinde inşa edilen mahalleye zemin oldu ve mahallenin merkezine konumlandı. Mahalle zemininde bulunan yaklaşık bir metrelik toprak katmanı alt yapı tesislerinin döşenmesi ve masif yapıların inşasının önünde engeldi. Temel atmadaki problem nedeniyle mahalle merkezinde sadece küçük bir kâgir mescit bulunuyordu. Kentin büyük meydanlarına, ana eksenine ve iktidar odağının yakınına yerleşmesi, mahallenin toplumsal içeriğini belirledi. On yedinci yüzyıl sonunda inşa edilen Bıyıklı Mustafa Paşa Sarayı, 1740 
senesine kadar Topkapı Sarayı́nın ardından en önemli iktidar odağının ikametgâhı, Paşa Kapısı'ydı. Sürekliliği olmayan yapıların birbiri ardına dizilmesi ve farklı işlevlerin mahallenin farklı yerlerinde toplanmış olması bu yüzyıldaki mahalle dokusunun ana özelliğidir. Bu durum on dokuzuncu yüzyıl ortalarında değişmiş ve birbiri ardına sıralanan haneler artık mahalle sahnesine egemen olmuştur.

Konutlar, mescidin etrafında değil, mahalleyi düz ve kesintisiz hatlarla ikiye bölen Yerebatan Caddesi üstüne dizilmişti. Birbiri ardına gelen yangınlar haneleri yok etse de mahallenin merkez doğrultusu olan caddenin izi değişmedi. On yedinci yüzyıl sonunda Divanyolu ekseninin başat bağlantılarından biri olan cadde, Ayasofya Camii ve Topkapı Sarayı arasında sadrazamın geliş gidiş güzergâhındaydı. 1803 tarihli plan, küçük bir çıkmaz sokak ve büyük parsellerin içinden geçip mahalleyi boydan boya ikiye ayıran Yerebatan Caddesi'ni sokak dokusunun yegâne temsilcileri olarak sunar. Mahallede, Salkım Söğüt Sokağı'nın varlığı bilinse de belirgin bir sokak dokusunun oluştuğunu söylemek zordur. On dokuzuncu yüzyıl ortasında parseller küçülmüştür. Bu dönemde artık caddeyi dikine kesen sokakların mahalle dokusunu belirlediği bir şemadan bahsedilebilir. Bu dönüşüm aşamasında da Yerebatan Caddesi, mahallenin morfolojik biçiminde merkez olarak kalmaya devam etti. Erişimin en kolay olduğu merkezdeki konumundan dolayı en değerli evler, camii, sebil, kütüphane, rüştiye binası gibi yapıların caddeye komşuluğu bulunmaktaydı.

\section{Kaynakça}

\section{Birincil Kaynaklar}

Atatürk Kitaplı̆̆

Hrt (Harita)

Cumhurbaşkanlığı Devlet Arşivleri BOA, A.MKT. (Sadaret, Mektubi Evrakı)

BOA, A.MKT.MHM. (Sadaret, Mektubi Mühimme Kalemi)

BOA, AE.SABH.I. (Ali Emiri, Abdülhamid)

BOA, BEO. (Babiali Evrak Odası Evrakı)

BOA, BEO.A.DVNSMHM.d (Bâb-1 Âsafi Divân-1 Hümâyun Mühimme Kalemi Defterleri)

BOA, C.AS. (Cevdet, Askeriye)

BOA, C.BLD. (Cevdet, Belediye)

BOA, C.DH. (Cevdet, Dahiliye)

BOA, C.MF. (Cevdet, Maarif)

BOA, C.ML. (Cevdet, Maliye)

BOA, D.BŞM. (Bab-1 Defteri, Başmuhasebe Kalemi Evrakı)

BOA, DH.i.UM. (Dahiliye Nezareti, İdare-i Umumiye)

BOA, DH.MKT. (Dahiliye Nezareti, Mektubi Kalemi)

BOA, HAT. (Hatt-1 Hümayun)

BOA, I.MMS. (İrade, Meclis-i Mahsus)

BOA, I.MVL. (Irade, Meclis-i Vala)

BOA, I.ŞD. (İrade, Şura-yı Devlet)

BOA, MAD.d. (Maliyeden Müdevver Defterler)

BOA, MF.IBT. (Maarif Nezareti, Tedrisat-1 ibtidaiyye Kalemi)

BOA, MF.MKT. (Maarif Nezareti, Mektubi Kalemi)

BOA, ML.VRD.d. (Maliye Nezareti, Varidat Muhasebesi)

BOA, MVL. (Meclis-i Vala Evrakı)

BOA, ŞD. (Şura-yı Devlet)

BOA, TS.MA.e. (Topkapı Sarayı Müzesi Arşivi)

Yayımlanmış Birincil Kaynaklar

Beyatlı, Ahmet, haz. Fâtih Sultan Mehmed'in 877/1472 Tarihli Vakfiyyesi. Ankara: Türk Tarih Kurumu, 2013.

Evliya Çelebi. Evliyâ Çelebi Seyahatnâmesi, Topkapı Sarayı Kütüphanesi Bağdat 304 Numaralı Yazmanın Transkripsiyonu-Dizini. Cilt 1. Hazırlayan Robert Dankoff, Seyit Ali Kahraman ve Yücel Dağlı. İstanbul: Yapı Kredi Yayınları, 2006.

Forcheimer, Philipp, ve Josef Strzygowski. Die Byzantinischen Wasserbehalter von Konstantinopel. Viyana: Verlag der Mechitharisten-Congregation, 1893.

Gyllius, Petrus. The Antiquities of Constantinople. Çeviren John Ball. Londra: 1729.

Hafız Hüseyin Ayvansarayi. The Garden of the Mosques. Çeviren Howard Crane. Leiden: Brill, 2000. 
Mehmed Ziya Bey. İstanbul ve Boğaziçi: Bizans ve Osmanlı Medeniyetlerinin Âsâr-ı Bâkıyesi. İstanbul: İBB Kültür A.Ş., 2016.

Pardoe, Julia. The Beauties of the Bosphorus. Londra: George Virtue, 1838.

Pertusier, Charles. Picturesque Promenades in and Near Constantinople, and on the Waters of the Bosphorus. Londra: Sir Richard Phillips and co., 1820.

Procopius. Buildings. Cilt 7. Çeviren B. Dewing ve Glanville Downey. Londra: Loeb Classical Library, 1971. Şem'dânî-zâde Fındıklılı Süleyman Efendi. Müri'itt-Tevârih. Cilt 1. Yayınlayan Münir Aktepe. İstanbul: İstanbul Üniversitesi Edebiyat Fakültesi Matbaası, 1976.

Walsh, Robert, ve Thomas Allom. İstanbul Manzaralart: Rumeli'de ve Batı Anadolu'da Gezintilerle. Çeviren Şeniz Türkömer. İstanbul: Türkiye İş Bankası Kültür Yayınları, 2013.

\section{ikincil Kaynaklar}

Altınay, Ahmet Refik. Fatma Sultan. İstanbul: Diken-İnci Matbaası, tarihsiz.

Altuğ, Kerim. "İstanbul'da Bizans Dönemi Sarnıçlarının Mimari Özellikleri ve Kentin Tarihsel Topografyasındaki Dağılımı.” Doktora Tezi, İstanbul Teknik Üniversitesi, 2013

Arseven, Celâl Esad. Istılâtât-ı Mi’mâriyye. Çeivren Şeyda Alpay. İstanbul: Kaknüs Yayınları, 2017.

Bozkurt, Nebi. "Sarnıç." TDV İslâm Ansiklopedisi. Cilt 36, 158-159. İstanbul: TDV Yayınları, 2009.

Byzantios, Scarlatos D. Constantinople: A Topographical, Archaeological, and Historical Description. Cilt 1. Çeviren Haris Theodorelis-Rigas. İstanbul: İstos, 2019.

Cerasi, Maurice. Divanyolu. Çeviren Ali Özdamar. İstanbul: Kitap Yayınevi, 2014.

Cezzar, Mustafa. "Osmanlı Devrinde İstanbul Yapılarında Tahribat Yapan Yangınlar ve Tabii Âfetler." Türk Sanatı Tarihi Araştırma ve Incelemeleri, c. I, yayınlayan Türk Sanatı Tarihi Enstitüsü, 327-414. İstanbul: Berksoy Matbaası, 1963.

Crow, James, Jonathan Bardill ve Richard Bayliss. The Water Supply Of Byzantine Constantinople. Londra: Society for the Promotion of Roman Studies, 2008.

Çeçen, Kazım, ve Celal Kolay. Topkapı Sarayına Su Sağlayan Isale Hatları. İstanbul: isKi, 1997.

Erdoğan, Muzaffer. Lale Devri Başmimarı Kayseri'li Mehmed Ağa. İstanbul: İstanbul Fetih Cemiyeti Yayınları, 1962.

Eyice, Semavi. "Yerebatan Sarayı.” Dünden Bugüne İstanbul Ansiklopedisi. Cilt 7, 503-504. İstanbul: Kültür Bakanlığı ve Tarih Vakfı, 1994.

İnalcık, Halil. The Survey of Istanbul 1455. İstanbul: Türkiye İş Bankası Kültür Yayınları, 2012.

Müller-Wiener, Wolfgang. İstanbul'un Tarihsel Topografyası. Çeviren Ülker Sayın. İstanbul: Yapı Kredi Yayınlar1, 2016.

Necipoğlu, Gülrü. Architecture, Ceremonial, and Power: The Topkapı Palace in the Fifteenth and Sixteenth Centuries. Cambridge: MIT Press, 1991.

Önlü, Şenhaz. "Yerebatan Sarnıcı'nın Taşıyıcı Elemanlarının Analizi.” Yüksek lisans tezi, İstanbul Teknik Üniversitesi, 2010.

Rossi, Aldo. The Architecture of the City. Derleyen Peter Eisenman, çeviren Diane Ghirardo ve Johan Oackman. Cambridge: MIT Press, 1984.

Yücel, Erdem. "İstanbul'da Bizans Sarnıçları." Arkitekt 325 (1967): 16-20. 